\title{
Potential of non-traditional isotope studies for bioarchaeology
}

\author{
Klervia Jaouen $^{1} \cdot$ Marie-Laure Pons $^{2}$
}

Received: 31 March 2016 / Accepted: 20 October 2016/Published online: 3 November 2016

(C) The Author(s) 2016. This article is published with open access at Springerlink.com

\begin{abstract}
As a consequence of recent developments in mass spectrometry, the application of non-traditional stable isotope systems (e.g. $\mathrm{Ca}, \mathrm{Cu}, \mathrm{Fe}, \mathrm{Mg}, \mathrm{Sr}, \mathrm{Zn}$ ) as well as radiogenic isotopes to archaeological materials is now possible. These techniques have opened new perspectives in bioarchaeology and can provide information on metabolism, diet and the mobility of past individuals. This review demonstrates this potential and describes the principle of these new analytical approaches. In addition, we emphasize how the "nontraditional" stable isotope systems compare and contrast with classic isotopic analyses.
\end{abstract}

Keywords Archaeological sciences - Metal stable isotopes · Tracers $\cdot$ Diet $\cdot$ Mobility $\cdot$ Metabolism

\section{Introduction}

\section{Notion of traditional and non-traditional isotopes}

The notion of traditional and non-traditional isotopes is usually applied to stable isotopes, which remain stable through

Klervia Jaouen and Marie-Laure Pons contributed equally.

Klervia Jaouen

Klervia_jaouen@eva.mpg.de

Marie-Laure Pons

mlp47@cam.ac.uk

1 Department of Human Evolution, Max Planck Institute for Evolutionary Anthropology, Deutscher Platz, 6, 04103 Leipzig, Germany

2 Department of Earth Sciences, Cambridge University, Downing Site, Cambridge CB2 3EQ, UK time, as opposed to radioactive isotopes that decay into a daughter isotope from a different element. This resulting daughter element is radiogenic. Radiogenic isotope abundances are typically expressed as the ratio of the radiogenic isotope of interest to a stable isotope of the same element (e.g. ${ }^{87} \mathrm{Sr} /{ }^{86} \mathrm{Sr}$ ). For stable isotope systems, the isotopic abundance is mostly measured in terms of delta notation (e.g. $\left.\delta^{18} \mathrm{O}\right)$. If a radiogenic isotope is involved, then the results are usually expressed as isotopic ratios.

For several decades, radiogenic isotopes strontium $(\mathrm{Sr})$ and lead $(\mathrm{Pb})$ and stable isotopes of light elements (hydrogen $(\mathrm{H})$, carbon $(\mathrm{C})$, nitrogen $(\mathrm{N})$, oxygen $(\mathrm{O})$, sulphur $(\mathrm{S})$ ) were the main isotopic systems studied in human remains (Fig. 1). Detection of natural stable isotope abundances for elements of masses greater than 40 amu was very difficult until recently. Two decades ago, the development of multi-collector inductively coupled plasma mass spectrometry (MC-ICP-MS) and thermal ionization mass spectrometry (TIMS) methods made the measurements of natural stable isotopic ratios for elements up to uranium easier (e.g. Ca: Skulan et al. 1997 (TIMS); Halicz et al. 1999 (ICP-MS); copper (Cu) and zinc ( $\mathrm{Zn})$ : Maréchal et al. 1999 (ICP-MS); iron (Fe): Walczyk 1997; Beard and Johnson 1999; Johnson and Beard 1999 (TIMS); Belshaw et al. 2000 (ICP-MS); magnesium (Mg): Richter et al. 1999 (TIMS); Galy et al. 2001 (ICP-MS)). These newly measured isotopes have been collectively referred to as "nontraditional stable isotopes" (Albarède and Beard 2004; Anbar and Rouxel 2007; Weiss et al. 2008).

Isotopic fractionation can occur during chemical or physical incomplete element transfer (Bigeleisen 1965; Albarède 2015). Isotopic fractionation is generally mass-dependent, particularly in living organisms, and has been observed for decades in the lighter elements such as C, N and S (DeNiro and Epstein 1978, 1981; McConnaughey and McRoy 1979; Schoeninger and DeNiro 1984; Kelly 2000; Richards et al. 

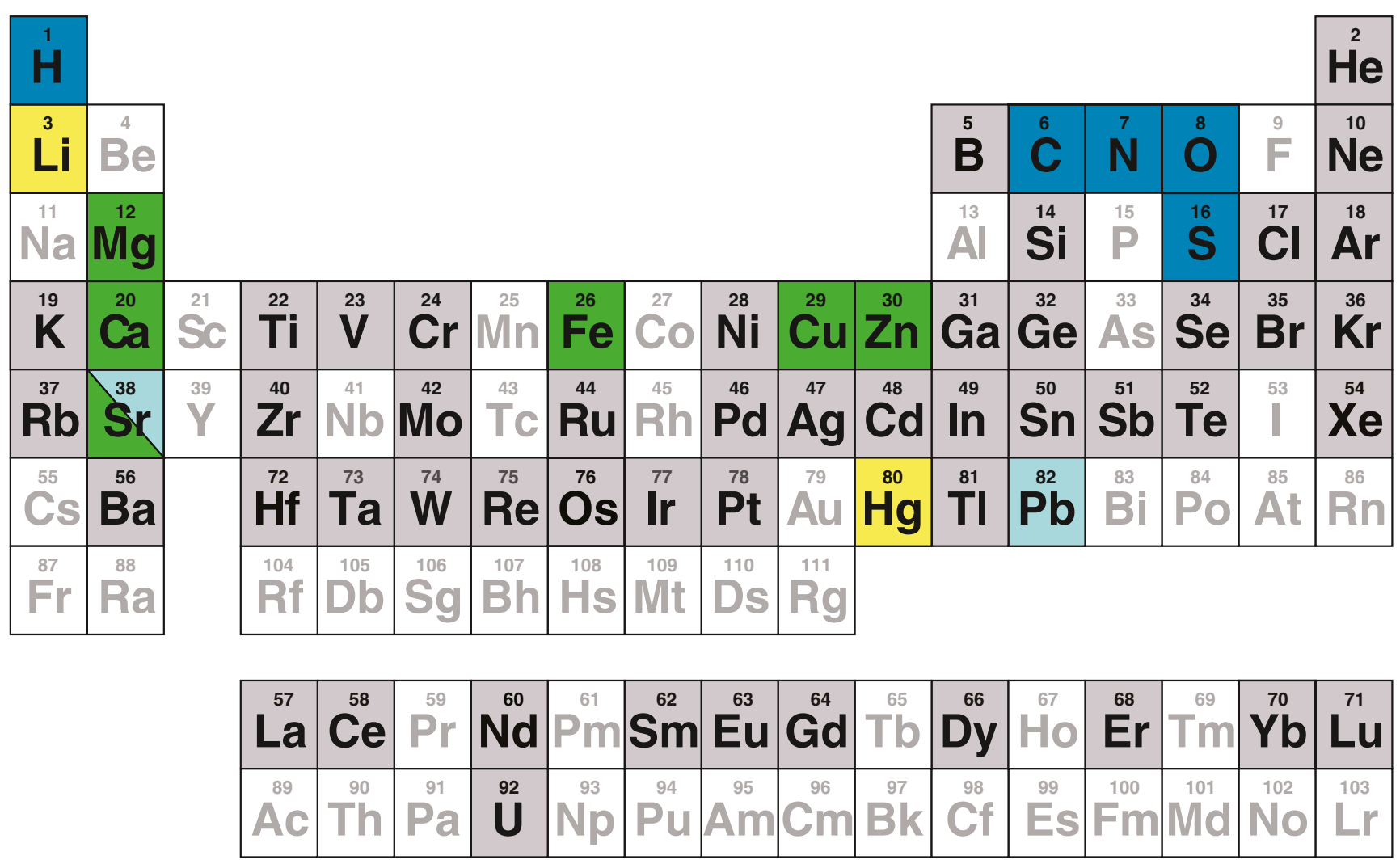

Fig. 1 Periodic table of the elements presenting traditional and nontraditional isotope compositions. Blue: Traditional stable isotopes including radiogenic ones (light blue). Green: Non-traditional isotopes that have been analysed in human remains. Yellow: Non-traditional isotopes that have been analysed in animal tissues. Grey: Nontraditional isotopes (including radiogenic isotopes) that have at least two stable isotopes
2001). Heavy isotopes of an element tend to have a higher affinity for the compounds where the element can form stiff bonds (Schauble 2004).

\section{"Traditional" stable and radiogenic isotope studies in archaeology}

Since the 1970s, isotopic tracers have been frequently used for dietary reconstructions (e.g. Vogel and Van der Merwe 1977; Van der Merwe and Vogel 1978, DeNiro and Epstein 1978, 1981). Historically, most studies on diet have relied on $\mathrm{C}$ and $\mathrm{N}$ isotopes in bone collagen. These isotopes can trace the consumption of meat, marine foods and C4 plants (maize, sorghum, millet) (Schoeninger and Moore 1992). Compared to sources of information on past diets such as zooarchaeology, organic residues, dental wear or dental calculus (e.g. Grayson 1984; Ryan and Johanson 1989; Dudd et al. 1999; Henry and Piperno 2008), these isotope systems provide a more quantitative approach on the food types eaten at the individual scale, as opposed to the population scale. The use of these isotopes has therefore been incredibly helpful for characterizing the diets and the social organization of our ancestors. However, the major downside of this technique is that it is time-limited: the collagen is not preserved for ancient sites (>100,000 years), or even for much younger sites, depending on the environmental context (Pestle and Colvard 2012). Therefore, information on meat and marine food consumption of ancient hominins is very difficult to retrieve. Carbon isotope studies on dental enamel provide useful information on the type of plants eaten by early hominins or their preys (Sponheimer and Lee-Thorp 1999; Sponheimer et al. 2006; Ungar and Sponheimer 2011) but fail documenting their trophic level. Some laser ablation trace element studies carried out on dental enamel have provided information for older specimens (Sponheimer et al. 2005; Balter and Simon 2006; Balter et al. 2012) but only allow assessment to the nearest trophic level and are highly dependent on the geology.

Oxygen isotopes can be analysed in bioapatite and mostly reflect the isotope composition of drinking water, which is in turn linked to the latitude and climate (Dansgaard 1964; Longinelli 1984; Evans et al. 2006). Consequently, these isotopes can be used for paleoenvironmental or mobility studies (e.g. White et al. 1998; Evans et al. 2006; Touzeau et al. 2013) but can also trace the dietary patterns of animals that primarily source 
their water from plants rather than free drinking water (Lee-Thorp and Sponheimer 2006). Hydrogen isotopes can provide similar information using various body tissues (Sharp et al. 2003; Fraser and Meier-Augenstein 2007; O'Brien and Wooller 2007; Ehleringer et al. 2008) but do not allow human provenance to be traced using bioapatite (Holobinko et al. 2011). Sulphur is also commonly used since recent analytical developments now require a smaller amount of collagen to perform $\mathrm{S}$ isotope analysis. Sulphur enters local food webs through atmospheric deposition, microbial processes active in soils and local bedrock. As sea spray has a very specific isotope signature, the $\delta^{34} \mathrm{~S}$ values can indicate coastal living environments (Richards et al. 2001; Richards et al. 2003; Zazzo et al. 2011; Nehlich 2015). As opposed to these light elements, heavier isotopes such as $\mathrm{Sr}$ and $\mathrm{Pb}$ are not easily fractionated during biological processes: the heavier the element of interest, the smaller the fractionation (Beard and Johnson 1999). A few decades ago, the same isotopic ratio was expected for heavy elements from the soil to the top of a trophic chain, in all organs and tissues (Gosz et al. 1983). With the recent improvement in mass spectrometry, this expectation has since been invalidated for a number of non-traditional isotopic systems: first for Fe isotopes (Beard and Johnson 1999) and recently for a much heavier element, mercury (Laffont et al. 2009, 2011). However, the heavy element isotopic system investigated in "traditional" archaeological studies is radiogenic strontium $\left({ }^{87} \mathrm{Sr} /{ }^{86} \mathrm{Sr}\right)$. The classical analytical procedure for the measurement of this ratio would erase any small biological fractionation, if present (Gosz et al. 1983). Indeed, for $\mathrm{Sr}$, all reported ${ }^{87} \mathrm{Sr} /{ }^{86} \mathrm{Sr}$ ratios are corrected for fractionation according to the measured deviation of the ${ }^{86} \mathrm{Sr} /{ }^{88} \mathrm{Sr}$ ratio in order to correct the instrumental fractionation mass bias (Gosz et al. 1983). As biological fractionation is mass-dependent, this protocol erases these small isotopic differences. This also applies to radiogenic lead (e.g. ${ }^{206} \mathrm{~Pb} /{ }^{204} \mathrm{~Pb}$ ), a system also used in bioarchaeological studies (e.g. Montgomery et al. 2000; Chiaradia et al. 2003; Turner et al. 2009). As a consequence, $\mathrm{Sr}$ and $\mathrm{Pb}$ radiogenic isotope compositions of human tissues reflect that of the soil where a living organism gets its food (animals or plants) (Bentley 2006). These isotope compositions are therefore frequently used to trace the mobility of past populations (e.g. Copeland et al. 2008; Richards et al. 2008; Copeland et al. 2011; Balter et al. 2012). Concentrations of radiogenic elements such as $\mathrm{Sr}$ and $\mathrm{Pb}$ increase over time. However, this increase does not matter for archaeology or biomedical studies because daughter isotope production is implemented beyond the timescale of interest or the lifetime of a living organism: the half-life of ${ }^{87} \mathrm{Rb}$ is $t_{1 / 2}=4923 \times 10^{10}$ years and the radionuclides involved in the U-Th series, which produce $\mathrm{Pb}$ isotopes, have halflives ranging from $10^{8}$ to $10^{10}$ years.

\section{Potential of "non-traditional" isotopes for archaeology}

As for traditional isotopes, the measurements of nontraditional isotope ratios have been developed by geochemists. While it was rarely undertaken at first, this type of analysis has become a discipline per se within the last 10 years (Albarède and Beard 2004; Anbar and Rouxel 2007). Initially, non-traditional stable isotope studies in biological materials have been mostly carried out on plants (e.g. Weiss et al. 2005; Guelke and von Blanckenburg 2007; Viers et al. 2007; Black et al. 2008; Moynier et al. 2009; von Blanckenburg et al. 2009; Aucour et al. 2011; Weinstein et al. 2011; Jouvin et al. 2012; Hindshaw et al. 2013) and human or animal tissues (e.g. Skulan and DePaolo 1999; Walczyk and von Blanckenburg 2002; Ohno et al. 2004; Ohno et al. 2005; Balter et al. 2010; Albarède et al. 2011; Balter et al. 2013; Sampson et al. 2013; Moynier et al. 2013; von Blanckenburg et al. 2014). They are now applied to biomedicine (e.g. Albarède et al. 2011; Morgan et al. 2011, 2012; Lauwens et al. 2016), archaeological artefacts (e.g. Desaulty et al. 2011; Albarède et al. 2012; Balliana et al. 2013; Delile et al. 2014; Baron and Coustures 2015) and human remains, which will be discussed throughout this review.

In order to apply the study of an isotopic system to the field of anthropology, the following two criteria must be met: (1) the selected element needs at least two stable isotopes, and (2) its isotope concentration in human organs or tissues needs to be above the detection limit of the mass spectrometer. Additionally, the isotope analyses of the element of interest first require the development of an extraction and purification protocol, as well as a minimum sample size to perform measurements for archaeological applications. A list of candidate elements is given in Fig. 1. At this time, only seven elements have been investigated for their isotopic composition in the human body: calcium $(\mathrm{Ca}), \mathrm{Cu}, \mathrm{Fe}, \mathrm{Mg}$, mercury $(\mathrm{Hg}), \mathrm{Sr}$ (stable isotopes) and $\mathrm{Zn}$ (Fig. 1). Copper, $\mathrm{Fe}$ and $\mathrm{Zn}$ isotopes are often studied together as they can be isolated using the same chemical purification protocol (Maréchal et al. 1999). Zinc data are the most abundant for several reasons: (1) $\mathrm{Zn}$ concentration is higher than that of $\mathrm{Cu}$ in body organs and tissues; (2) $\mathrm{Zn}$ isotopic measurements require less advanced technology relative to $\mathrm{Fe}$ isotopes; and (3) the chemical purification of $\mathrm{Zn}$ alone (Moynier et al. 2006) is cheaper and less time-consuming.

Natural isotopic abundances of the abovementioned elements and their associated delta notation are given in Table 1 . Three factors are likely to trigger isotopic variability within the human body: 
Table 1 Abundances of stable isotopes for elements studied for their non-traditional isotope compositions

\begin{tabular}{|c|c|c|c|c|c|}
\hline Element & Symbol & Group & Abundances & Delta notation & $\begin{array}{l}\text { Radiogenic } \\
\text { ratio }\end{array}$ \\
\hline Calcium & $\mathrm{Ca}$ & Alkaline earth metal & $\begin{array}{l}{ }^{40} \mathrm{Ca}^{\mathrm{a}}(96.9 \%),{ }^{42} \mathrm{Ca}(0.6 \%),{ }^{43} \mathrm{Ca}(0.1 \%),{ }^{44} \mathrm{Ca}(2.1 \%), \\
{ }^{46} \mathrm{Ca}^{\mathrm{a}}(0.004 \%),{ }^{48} \mathrm{Ca}^{\mathrm{a}}(0.2 \%)\end{array}$ & $\begin{array}{r}\delta^{44 / 42} \mathrm{Ca}(\mathrm{ICP}-\mathrm{MS}) \\
\delta^{44 / 40} \mathrm{Ca}(\mathrm{TIMS})\end{array}$ & \\
\hline Copper & $\mathrm{Cu}$ & Transition metal & ${ }^{63} \mathrm{Cu}(69.2 \%),{ }^{65} \mathrm{Cu}(30.9 \%)$ & $\delta^{65} \mathrm{Cu}$ & \\
\hline Iron & $\mathrm{Fe}$ & Transition metal & ${ }^{54} \mathrm{Fe}(5.8 \%),{ }^{56} \mathrm{Fe}(91.7 \%),{ }^{57} \mathrm{Fe}(2.2 \%)$ and ${ }^{58} \mathrm{Fe}(0.3 \%)$ & $\delta^{56} \mathrm{Fe}, \delta^{57} \mathrm{Fe}$ & \\
\hline Magnesium & $\mathrm{Mg}$ & Alkaline earth metal & ${ }^{24} \mathrm{Mg}(79.0 \%),{ }^{25} \mathrm{Mg}(10.0 \%),{ }^{26} \mathrm{Mg}(11.0 \%)$ & $\delta^{25} \mathrm{Mg}, \delta^{26} \mathrm{Mg}$ & \\
\hline Strontium & $\mathrm{Sr}$ & Alkaline earth metal & ${ }^{84} \mathrm{Sr}(0.6 \%),{ }^{86} \mathrm{Sr}(9.9 \%),{ }^{87} \mathrm{Sr}(7.0 \%),{ }^{88} \mathrm{Sr}(82.6 \%)$ & $\delta^{88} \mathrm{Sr}$ & ${ }^{87 / 86} \mathrm{Sr}$ \\
\hline Zinc & $\mathrm{Zn}$ & Transition metal & $\begin{array}{l}{ }^{64} \mathrm{Zn}^{\mathrm{a}}(49.2 \%),{ }^{66} \mathrm{Zn}(27.7 \%),{ }^{67} \mathrm{Zn}(4.0 \%), \\
{ }^{68} \mathrm{Zn}(18.5 \%),{ }^{70} \mathrm{Zn}^{\mathrm{a}}(0.6 \%)\end{array}$ & $\delta^{66} \mathrm{Zn}, \delta^{67} \mathrm{Zn}, \delta^{68} \mathrm{Zn}$ & \\
\hline
\end{tabular}

${ }^{\mathrm{a}}$ Isotopes that are observed stable but actually radioactive

(1) Diet: isotopic fractionation can occur during intestinal absorption or excretion, inducing isotopic differences between the body isotopic compositions of a prey animal and its predator. Predator-prey isotopic differences can be observed for instance in the case of $\mathrm{N}$ isotopes (Fig. 2). Significant isotopic differences between food categories belonging to the same trophic level can also exist, and the consumption of these different food categories can therefore be traced (e.g. ${ }^{13} \mathrm{C}$ isotope compositions of $\mathrm{C}_{3} / \mathrm{C}_{4}$ plants). (2) Environmental context: like the radiogenic ratio of $\mathrm{Sr}\left({ }^{87} \mathrm{Sr} /{ }^{86} \mathrm{Sr}\right)$, isotope composition of the soil can impact that of the whole food web. (3) Metabolism: metabolic reactions within the body can also generate isotope fractionation. Metabolic processes such as disease could therefore be traced. This is particularly true for non-traditional isotopes: unlike traditional ones, they do not belong to the $\mathrm{CHNOPS}^{1}$ (Fig. 1), that is to say the most common elements in living organisms. They are therefore more likely to trace specific metabolic processes, being involved in less biological reactions. When a dietary, environmental or metabolic process triggers major isotope variability of one element, its isotope composition can be used to trace the process of interest (Fig. 2). As a consequence, isotope studies carried out on human tissues can help reconstruct the diet, mobility and health conditions of past populations.

In this review, we will assess the natural distribution of these isotopic systems in food webs and their established or potential contribution for bioarchaeological studies. We will show that they can be used alongside $\mathrm{Sr}$ radiogenic ratios and light stable isotopes for palaeodiet, weaning and mobility tracing, but we will also discuss how they could be used to investigate other processes, such as biological sex or age at menopause. Often, the studies reported in this review offer only preliminary conclusions but constitute pioneer research: even if non-traditional stable isotope studies are still in their infancy, their potential as promising new archaeological tools has already been shown.

\footnotetext{
${ }^{1}$ CHNOPS stands for carbon hydrogen, nitrogen, oxygen, phosphorus and sulphur
}

\section{Material and methods in non-traditional isotope studies}

\section{Material}

\section{Material candidates for non-traditional isotope analyses}

All of the non-traditional isotope systems investigated in human remains have been established in bioapatite, a calcium phosphate $\left(\mathrm{Ca}_{10}\left(\mathrm{PO}_{4}\right)_{6}(\mathrm{OH})_{2}\right)$ located in dental enamel and tooth dentine as well as in the mineral part of bones. Besides the classic isotope measurements of $\mathrm{O}, \mathrm{Ca}$ isotope compositions can also be measured (Firestone and Shirley 1998). Phosphorus, having only one stable isotope, does not meet the criteria for isotope studies (Fig. 1). Amongst the minor elements, $\mathrm{Mg}$ isotope compositions have been described in bone and teeth (Martin et al. 2014, 2015b). Magnesium substitutes to $\mathrm{Ca}$ in the bioapatite lattice. This substitution mechanism also applies to several trace elements such as $\mathrm{Zn}$ and $\mathrm{Sr}$ (Gross and Berndt 2002). The incorporation process of Fe and $\mathrm{Cu}$ in bioapatite is unclear but could also be a substitution to $\mathrm{Ca}$ atoms. Iron and $\mathrm{Zn}$ isotopes have also been measured in human hair, with a minimum amount of $100 \mathrm{mg}$ required for one measurement (Stenberg et al. 2004; Ohno et al. 2005). The mass required for analyses first depends on the concentration of the element of interest in the chosen archaeological material. At a smaller but still important scale, it is also a function of the mass spectrometer used for the isotopic measurements, the isotopes that can be analysed, as well as their abundances. These masses are summarized in Table 2. Depending on the material chosen for analysis, the isotopic signal will represent different periods of the life of past individuals. Bones are renewed throughout life while dental enamel and dentine do not change after their formation. Dental tissues therefore record the isotopic signature of childhood, and bones average the last 5 to 20 years of life (Pate 1994; Sealy et al. 1995; Hedges et al. 2007). Independent of this temporal difference, bone and dental enamel do not exhibit the same isotope composition, whatever the element 
Fig. 2 The woman template originates from the pioneer plaque (NASA, no copyright). Factors influencing traditional and non-traditional isotope compositions of different elements of the human body

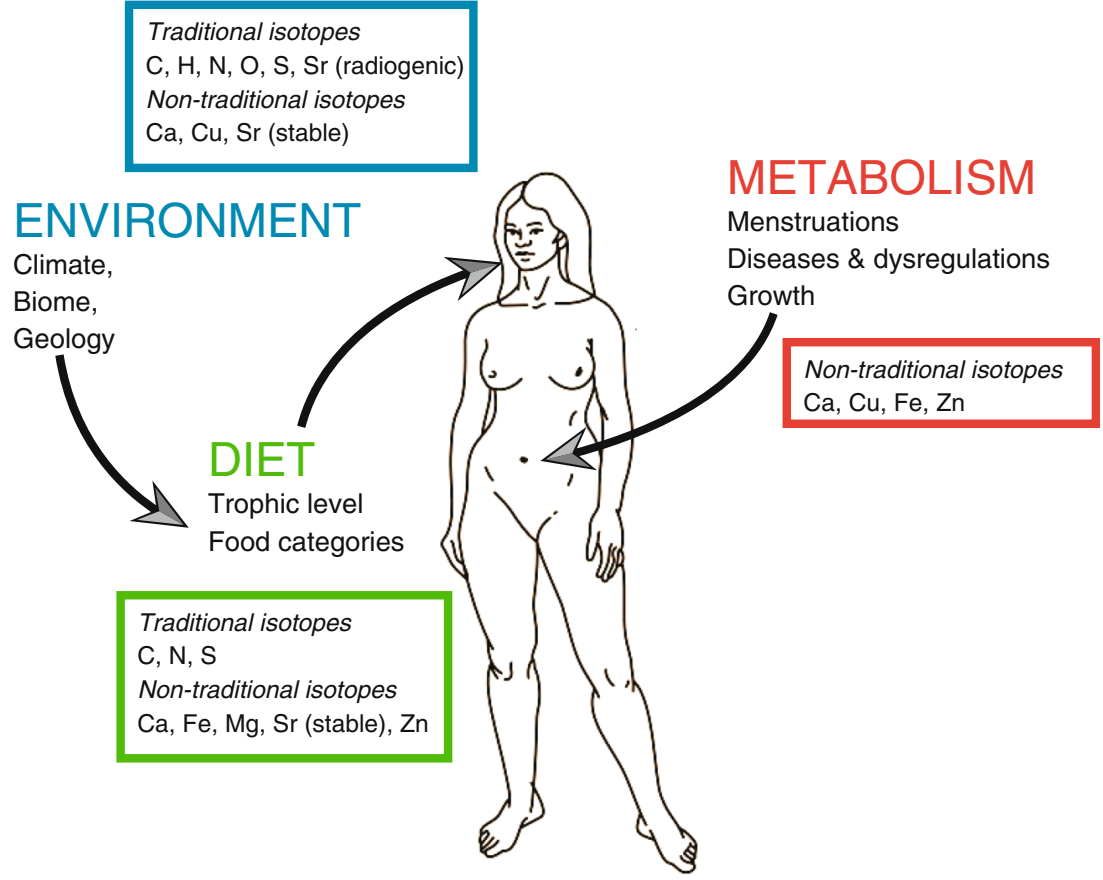

considered. Offsets between bone and dental enamel isotopic values have been reported for all the elements in which isotopic compositions have been measured in these two tissues $(\mathrm{C}$ and O (Warinner and Tuross 2009), Ca (Heuser et al. 2011), Mg (Martin et al. 2014), Zn (Jaouen et al. 2016a)), though never really explained.

\section{Diagenesis}

When choosing a material for non-traditional isotope analyses, careful attention has to be paid to potential soil contamination. Bone and dentine are more porous than dental enamel and are therefore more likely to incorporate elements from aqueous fluids circulating in soils (Reynard and Balter 2014). This problem is obviously more relevant for trace elements: it has been shown that diagenesis of archaeological bones is not likely to overprint the biogenic signature of $\mathrm{Ca}$ isotopes (Reynard et al. 2010), even though it might happen for very old bones such as those of dinosaurs (Heuser et al. 2011). On the other hand, some elements such as $\mathrm{Fe}$ are present as traces in human remains ( $\sim 100 \mathrm{ppm})$ but show very high concentrations in soil (1 to $40 \%$ ). Depending on the environmental context, historical bones can incorporate high levels of diagenetic Fe, which will overprint the isotopic composition of interest (Kohn et al. 1999; Martínez-García et al. 2005). Several tests have been described in the literature to investigate bone diagenesis: collagen preservation, REE content, crystallinity index, Ca/P ratios, etc. (Price et al. 1992; Hedges 2002; Beasley et al. 2014; Reynard and Balter 2014). However, it has been shown that these tests trace different diagenetic processes that are not necessarily related (Trueman et al. 2008). Recrystallization can occur in a bone with preserved trace element content, but geochemical perturbations can also happen without detectable change of crystallinity (Pucéat et al. 2004). To overcome this problem, Reynard and Balter (2014) suggested using a diagenetic test involving the trace element of interest. This test consists of assessing if the trace element isotopic compositions of various samples from a site are correlated to their concentrations, which is expected if these samples incorporated various proportions of a diagenetic component (Albarède 1996). Dental enamel is generally considered much more preserved because of a higher degree of mineralization and low porosity (Lee-Thorp and van der Merwe 1991; Wang and Cerling 1994; Hoppe et al. 2003; Lee-Thorp and Sponheimer 2003). It is considered a material of choice for trace element analyses. However, depending on the age and the environmental context of the sample, diagenesis can affect the integrity of biogenic signatures in dental enamel (Kohn et al. 1999; Schoeninger et al. 2003) and should be assessed.

\section{Methods}

\section{Sample preparation}

Most of the non-traditional isotope systems' elements are present in minor or trace concentrations in teeth and bones. Therefore, their analyses using mass spectrometry require the removal of the matrix, in order to avoid isobaric interferences with isotopes of other elements or molecules of the same mass. 


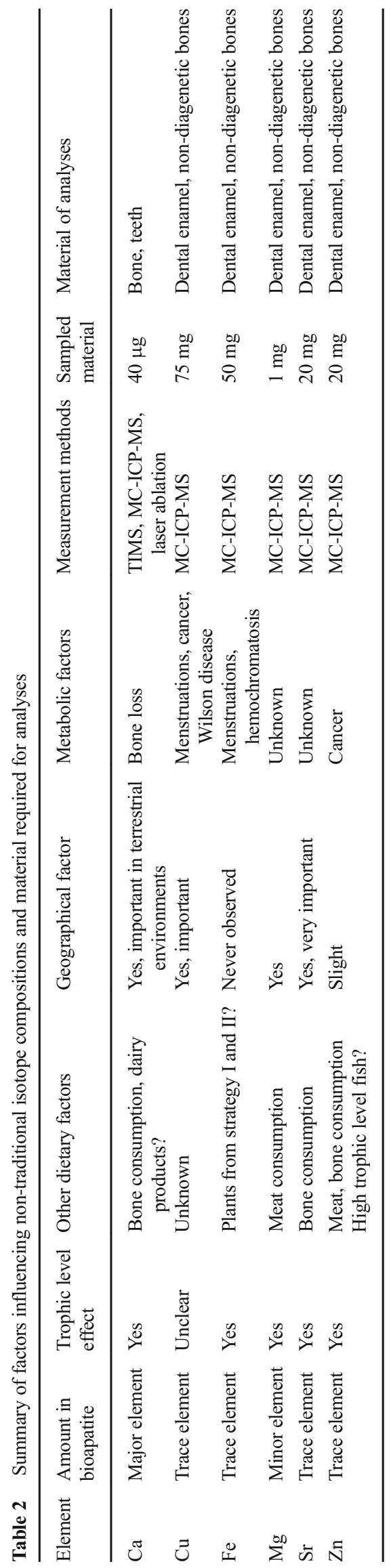

For example, a molecule made of the major isotopes of $\mathrm{Ca}$ and $\mathrm{O}\left({ }^{40} \mathrm{Ca}\right.$ and $\left.{ }^{16} \mathrm{O}\right)$ is likely to interfere with one of the $\mathrm{Fe}$ isotopes $\left({ }^{56} \mathrm{Fe}\right)$, inducing a bias in the measurement of the $\delta^{56} \mathrm{Fe}$ values. This purification step is achieved using chromatography on columns. If the element of interest is a major element, the purification step will not be mandatory, as shown in blood by Anoshkina et al. (2015) for Fe isotopes. However, in the case of $\mathrm{Ca}$, which represents almost one atom out of two in bioapatite, the removal of the matrix is required to avoid destabilization of the plasma due to the presence of phosphorus. The protocols used for $\mathrm{Ca}, \mathrm{Fe}, \mathrm{Cu}$ and $\mathrm{Zn}$ purifications prior to isotopic analyses have recently been summarized by CostasRodriguez et al. (2016). The purification of Mg has been described by Martin et al. (2014), whereas the technique employed for stable isotope compositions of Sr remains unpublished. The purification protocol used for the radiogenic ratio of strontium $\left({ }^{87} \mathrm{Sr} /{ }^{86} \mathrm{Sr}\right)$ is not quantitative and cannot be used for $\delta^{88} \mathrm{Sr}$ assessments (Hartman and Richards 2014). Incomplete recovery of an element during ion exchange resin chromatography on columns triggers significant isotopic fractionation on non-radiogenic stable isotope ratios (Maréchal et al. 1999).

\section{Isotopic analyses}

Isotopic ratios of trace elements are measured using TIMS or MC-ICP-MS. The main difference between these two instruments consists of how the sample is introduced and ionized, but the analytical aspect of these techniques is similar. The TIMS measurements are usually more precise but also time-consuming. Most of the non-traditional isotopes are analysed using MC-ICP-MS (Costas-Rodríguez et al. 2016, Table 2), with the exception of $\mathrm{Ca}$ isotopes that are analysed using either technique (e.g. Skulan and DePaolo 1999; Heuser and Eisenhauer 2010; Reynard et al. 2010; Tacail et al. 2014). In the case of MC-ICP-MS instrumentation, the ratio measured will be ${ }^{44} \mathrm{Ca} /{ }^{42} \mathrm{Ca}$, instead of the ${ }^{44} \mathrm{Ca} /{ }^{40} \mathrm{Ca}$ ratio. This technique uses argon as a carrier gas, which interferes with the isotope ${ }^{40} \mathrm{Ca}$. Stable isotope fractionation is mass-dependent, which implies that $\delta^{44 / 42} \mathrm{Ca}=\delta^{44 / 40} \mathrm{Ca} \times \frac{\left(1 / m_{42}-1 / m_{44}\right)}{\left(1 / m_{40}-1 / m_{44}\right)}$, that is too say $\delta^{44 /}$ ${ }^{42} \mathrm{Ca}=0.4773 \times \delta^{44 / 40} \mathrm{Ca}$ (Young et al. 2002; Sime et al. 2007). Details on non-traditional isotope measurements have been described by Albarède and Beard (2004).

Recent studies demonstrated the possibility of measuring non-traditional isotope compositions of human tissues using laser ablation. Protocols for $\mathrm{Ca}$ isotope laser analyses were recently developed for biological or synthetic apatite (Tacail et al. 2016; Li et al. 2016). Isotopic measurements of other elements may be more difficult to achieve because of the low abundance of $\mathrm{Fe}, \mathrm{Zn}, \mathrm{Cu}$ or $\mathrm{Mg}$ in bioapatite but not impossible as shown by Resano et al. (2013), who measured the $\mathrm{Cu}$ isotopic composition of dried urine pellets. 


\section{Diet and non-traditional isotope compositions}

Two dietary factors are likely to impact isotopic compositions of human bodies: (1) the actual isotopic compositions of food products and (2) the fractionation occurring during intestinal absorption, which can be influenced by the atomic environment of the element of interest and, therefore, the food category. For instance, the precipitation of $\mathrm{Zn}$ with phytates contained in plants, which happens within the intestinal tract, seems to be isotopically selective towards light isotopes (Jaouen et al. 2013b). The consumption of plants is therefore associated with an enrichment of the consumer tissues in $\mathrm{Zn}$ heavy isotopes, which are more bioavailable ${ }^{2}$. In the case of animal product consumption, there is no evidence of an existing process influencing the bioavailability ${ }^{2}$ of one isotope over another and no fractionation apparently occurs during intestinal absorption (Jaouen et al. 2013b). Another illustration of these two dietary factors can be given by the carbon isotope compositions of food products. Marine fish tissues and $\mathrm{C}_{3}$ plants generally exhibit a discrepancy of $\approx 15 \%$, whereas the isotope fractionation during intestinal absorption is approximately 0 to $2 \%$ for the two food categories (Bocherens and Drucker 2003). As a consequence, the actual isotope composition of food products is the main factor of $\mathrm{C}$ isotope variations in the human body. In the case of $\mathrm{N}$ isotopes, an isotope fractionation of 3 to $5 \%$ o between the bone collagen and the food product can be observed, and this significant increase can therefore be used as an indicator of the trophic level (Hedges and Reynard 2007). An important step for the calibration of new dietary tracers is the investigation of the existence of a trophic level effect, as well as the identification of food categories with a specific isotope composition.

\section{Trophic level effect}

The existence of a trophic level effect has been demonstrated for most of the non-traditional isotopic systems studied so far: Ca (Clementz et al. 2003; DePaolo 2004; Heuser et al. 2011; Martin et al. 2015a), Mg (Martin et al. 2014; Martin et al. 2015b), Sr (Knudson et al. 2010; Tütken et al. 2015), Zn (Van Heghe et al. 2012; Costas-Rodríguez et al. 2014; Jaouen et al. 2016a, 2016b) and Fe (Walczyk and von Blanckenburg 2002; Walczyk and von Blanckenburg 2005; Jaouen et al. 2013b; von Blanckenburg et al. 2013). For Ca, this pattern is not systematically observed (Melin et al. 2014). This trophic level effect can correspond to an enrichment in light isotopes through the trophic chain (like for $\mathrm{C}$ and $\mathrm{N}$ isotopes) or a depletion. Enrichment in light isotopes can also be observed for elements such as $\mathrm{Ca}, \mathrm{Fe}$ and $\mathrm{Sr}$ but not for $\mathrm{Mg}$,

\footnotetext{
${ }^{2}$ Bioavaibility is potential absorption of a chemical species as a function of external factors such as the food matrix and the chemical form of the element in question.
}

$\mathrm{Cu}$ and $\mathrm{Zn}$ (Fig. 3, Tütken et al. 2015). The case of $\mathrm{Zn}$ is very peculiar: as mentioned before, a plant-based diet seems to trigger the preferential intestinal absorption of $\mathrm{Zn}$ heavy isotopes, whereas no fractionation is expected in a meat-based diet, due to a quantitative absorption of the element (Lönnerdal 2000; Jaouen et al. 2016a, 2016b). However, because animal muscles are depleted in heavy $\mathrm{Zn}$ isotopes compared to the bulk isotope composition of the body, body tissues of meat consumers have lower isotope compositions than those of their prey (Jaouen et al. 2016a, 2016b, Fig. 3). Similarly, von Blanckenburg et al. (2013) have shown that vegetarian diets are associated with a $\mathrm{Fe}$ isotopic fractionation factor 1.5 times higher than that of omnivore diets, but in this case, the light isotopes are preferentially absorbed. Because the $\mathrm{Fe}$ isotope composition of vegetarians' diet is generally much higher than that of omnivores, the blood isotope compositions of these two groups are similar and cannot be distinguished (Van Heghe et al. 2012; von Blanckenburg et al. 2013). It should be noted that ovo-lacto-vegetarian and omnivore diets both mix animal and plant products. The difference reported between herbivore and carnivore $\mathrm{Fe}$ isotope compositions could therefore be due to pure meat and plant-based diets. Mercury isotopes, a system not yet investigated in archaeological materials, also show a preferential selection for light isotopes by living organisms. Laffont et al. (2009) reported enrichment of $0.5 \%$ relative to the atomic mass when comparing $\delta^{202} \mathrm{Hg}$ values between fish and humans, and Gehrke et al. (2011) observed an enrichment of about $0.6 \%$ between fish and sediments (which contain the primary source of dietary $\mathrm{Hg}$ ). As expected, the range of fractionation within a trophic chain is about 10 times smaller for alkaline earth and transition metals than for lighter elements like nitrogen and carbon isotopes (Fig. 3).

\section{Traceability of food categories}

\section{Plant consumption}

The existence of isotope variability amongst plants has been documented for $\mathrm{Ca}$ (von Blanckenburg et al. 2009; Hindshaw et al. 2013), $\mathrm{Cu}$ (Weinstein et al. 2011; Jouvin et al. 2012), Fe (Guelke and von Blanckenburg 2007; von Blanckenburg et al. 2009), Mg (Black et al. 2008) and Zn (Weiss et al. 2005; Viers et al. 2007; Moynier et al. 2009; Aucour et al. 2011; Jouvin et al. 2012). Isotopic fractionation occurs within a plant, leading to different isotopic compositions between the roots, stems and leaves. Therefore, we can expect isotopic differences between browsers (which have a leaf-based diet) and grazers (which mostly feed on grasses). So far, this difference has been observed for $\mathrm{Mg}$ (Martin et al. 2015b) and $\mathrm{Zn}$ isotopes (Jaouen et al. 2016a). Significant differences have also been observed in the $\mathrm{Fe}$ isotope composition of plants 


\section{Traditional stable isotopes}
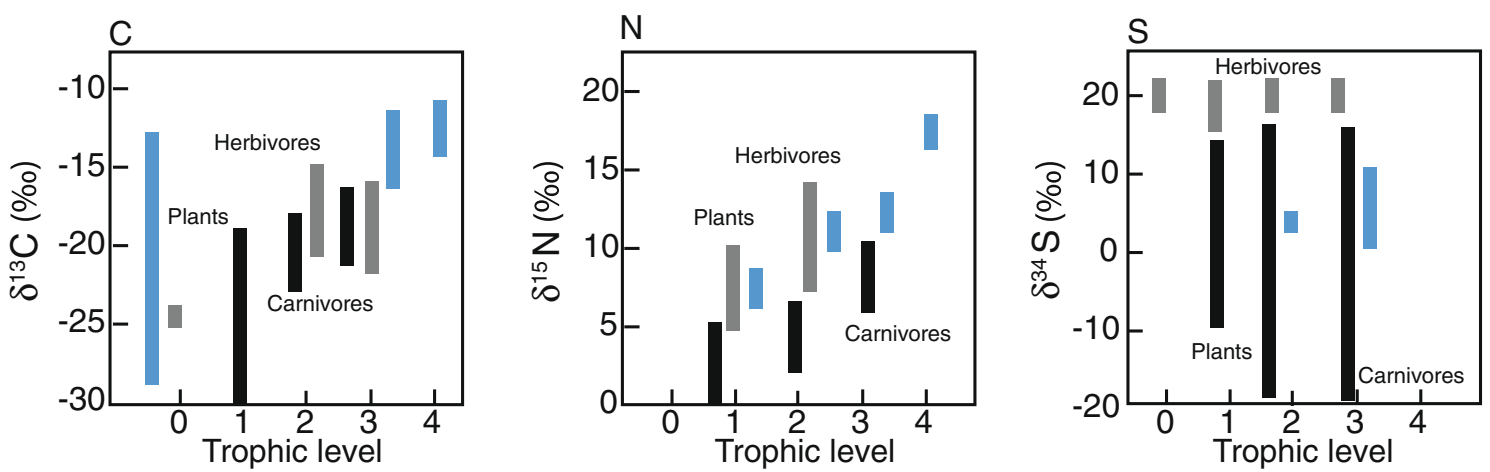

Non-traditional stable isotopes
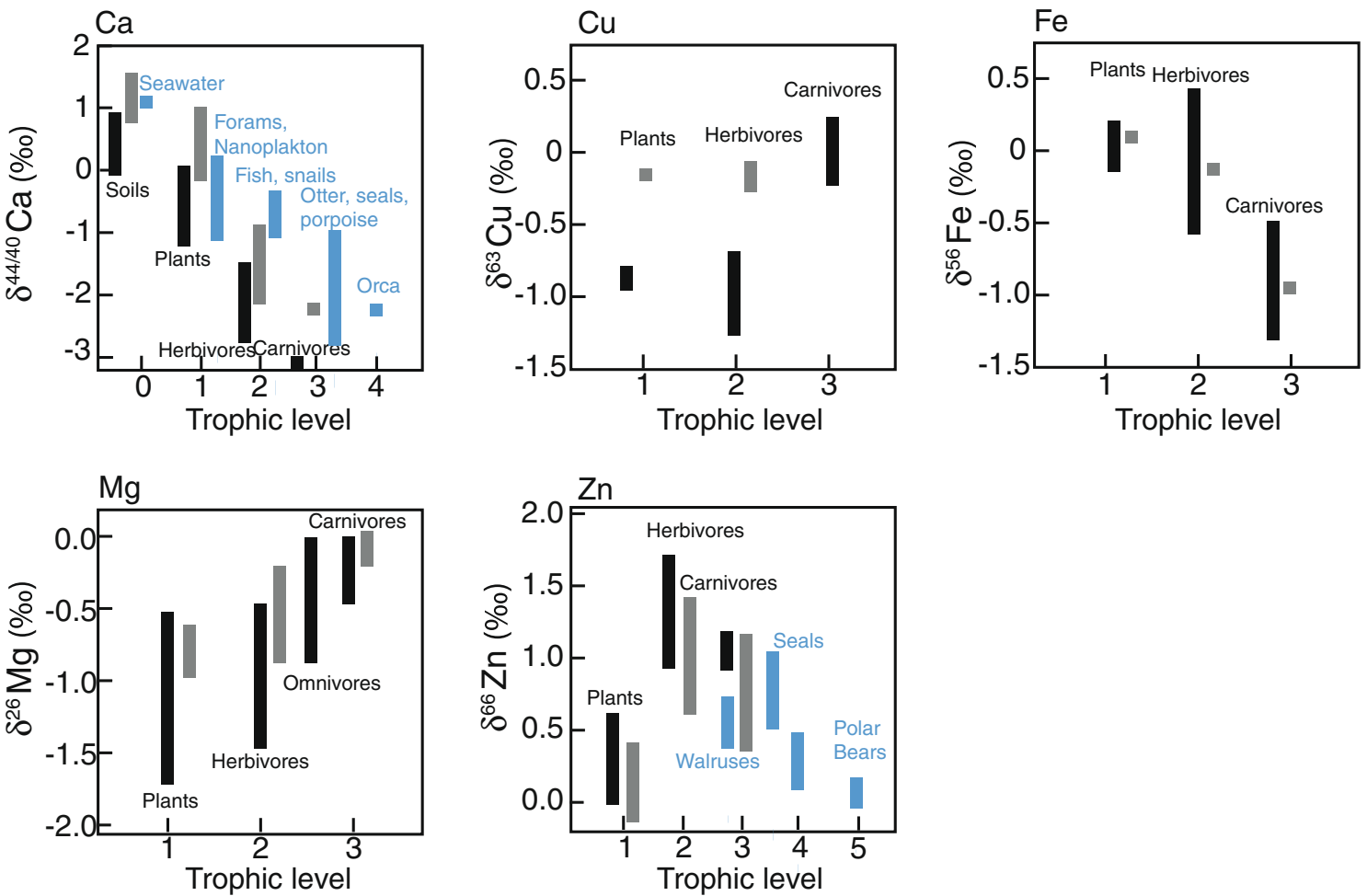

Fig. 3 Trophic level effect on classic and non-traditional isotope compositions. Blue colours correspond to a marine environment. Black and grey correspond to two different terrestrial food webs. After McConnaughey and McRoy (1979) and Schoeninger and DeNiro (1984) (C isotopes), Minagawa and Wada (1984), Kelly (2000) and

using a different strategy for Fe mobilization and uptake from the soils (Guelke and von Blanckenburg 2007). This strategy is confined to grasses, whereas the preceding strategy is used by all other types of plants (Marschner and Römheld 1994). The plants using the first strategy, such as vegetables, usually show lower $\delta^{56} \mathrm{Fe}$ values relative to plants using the second strategy, such as crops. The Fe isotopic signature of the consumption of only one of these two plant types has yet been investigated.
Schoeninger and DeNiro (1984) (N isotopes), Nehlich (2015) (S isotopes), Skulan and DePaolo (1999), Clementz et al. (2003) and DePaolo (2004) (Ca isotopes) and Jaouen et al. (2013a, 2016a, 2016b) (Cu, Fe and $\mathrm{Zn}$ isotopes) and Martin et al. (2014, 2015b) (Mg isotopes)

\section{Bone consumption}

Isotopic compositions of body tissues are highly variable within an organism (Skulan and DePaolo 1999; Walczyk and von Blanckenburg 2005; Balter et al. 2010; Balter et al. 2013; Moynier et al. 2013; Balter and Vigier 2014). Consequently, the consumption of specific organs or tissues could impact the isotopic signature of carnivore body tissues. Bones are enriched in $\mathrm{Zn}$ heavy isotopes and $\mathrm{Ca}$ light isotopes 
relative to muscles. It seems that the bone consumption occurring in some carnivore species, such as hyenas, impacts the isotopic signature of their bones and teeth, making them distinguishable from pure meat-feeders (Tütken et al. 2015; Jaouen et al. 2016a). However, these recent findings need further investigation to be confirmed.

\section{Dairy consumption}

Most dietary $\mathrm{Ca}$ comes from dairy products and vegetables, so meat and water can be considered negligible sources (Chu et al. 2006; Heuser and Eisenhauer 2010). In 2006, Chu et al. (2006) analysed herbivore milk and discovered very low $\delta^{44 / 42} \mathrm{Ca}$ values, depleted by about $0.5 \%$ relative to the diet of these animals. They also analysed dairy products such as curd and whey and showed that fermentation processes do not induce significant isotopic fractionation. They suggested that $\mathrm{Ca}$ isotopes could be used to trace dairy product consumption. Reynard et al. (2011) tested this hypothesis by comparing bones from Epipalaeolithic and Mesolithic sites, where dairy consumption is unlikely, to bones from a medieval site. They systematically observed an enrichment of human bones in light $\mathrm{Ca}$ isotopes compared to the faunal bones, but the range of fractionation was the same for each site (0.2-0.4\%o, Reynard et al. 2011). As a result, the trophic level effect seems to overprint the isotope signature of dairy product consumption.

\section{Breastfeeding and weaning}

The relationship between the breastfed child and the mother is similar to the prey-predator relationship from a dietary point of view. The trophic level of the child is higher than that of the mother until weaning. Following this idea, numerous studies investigate the breastfeeding duration in archaeological populations using light stable isotopes, mostly $\delta^{15} \mathrm{~N}$ values (Richards et al. 2002; Fuller et al. 2006; Herrscher 2013), but also with $\delta^{13} \mathrm{C}$ and $\delta^{34} \mathrm{~S}$ (Wright and Schwarcz 1998; Richards et al. 2002; Nehlich et al. 2011). These analyses are carried out on bone proteins, which are not always preserved. As a consequence, major elements contained in the mineral phase are of great concern for weaning pattern assessment. Attempts have been performed using $\mathrm{O}$ isotopes on dental enamel carbonates but provided contradictory results (Wright and Schwarcz 1998; Williams et al. 2005; Herrscher 2013). Non-traditional isotopes could therefore be of interest for weaning age assessment. As mentioned before, milk also has low $\delta^{44 / 42} \mathrm{Ca}$ values. Human milk is no exception as it corresponds to the lowest ${ }^{44} \mathrm{Ca} /{ }^{42} \mathrm{Ca}$ ratios measured in biological material alongside bones (Chu et al. 2006; Reynard et al. 2010). It has therefore been suggested that $\mathrm{Ca}$ isotopes could be used as weaning indicators (Chu et al. 2006). Reynard et al. (2013) tested this assumption using human archaeological populations from the Turkish Neolithic site Așıklı Höyük and skeletons from Christ Church, Spitalfields, buried during the eighteenth century. At Așıklı Höyük, Ca isotope ratios in milk-consuming infants and juveniles were lower than those of adults, as expected. Also, $\delta^{44 / 42} \mathrm{Ca}$ correlates to $\delta^{15} \mathrm{~N}$ values. However, at Spitalfields, no significant differences between age group and no correlation with traditional stable isotopes have been observed (Reynard et al. 2013). Wright (2014) observed a weaning pattern in sheep tooth enamel by comparing the $\mathrm{Ca}$ isotope compositions of modern teeth formed successively during their infancy. These contradicting results remain unexplained. More work is needed to understand the impact of diet and metabolism on $\mathrm{Ca}$ isotopes in the human body, in order to fully recognize their potential for archaeological studies. Some efforts have however already been made by combining isotope analyses with box models (Skulan and DePaolo 1999; Heuser and Eisenhauer 2010). The results shed light on the fundamental role of both mineral bone balance and Rayleigh type $\mathrm{Ca}$ isotope fractionation in the kidneys on $\mathrm{Ca}$ isotope compositions of body tissues.

\section{Environmental context and non-traditional isotope compositions}

Assessing the interpopulation variability is a crucial step in non-traditional isotope studies in a bioarchaeological perspective. High variability between different sites opens up possibilities for developing mobility proxies. Two factors are likely to generate isotopic variations in soils: (1) the local geology and (2) environmental processes related to the vegetation, water circulation and climate.

Differences between the isotopic composition of animal or human remains coming from different locations have been documented for Ca (Reynard et al. 2010), $\mathrm{Cu}$ (Jaouen et al. 2013b), Mg (Martin et al. 2014) and $\mathrm{Sr}$ (stable isotopes, Knudson et al. 2010) (Figs. 3 and 4). On the other hand, Fe isotopic composition of animal and human remains seems to be homogenous wherever the provenance (Jaouen et al. 2013b). This is also true for Fe isotopes in human blood (Jaouen et al. 2013a), with the exception of a Thai female population, which exhibits blood Fe isotope compositions lower than expected (Fig. 4, Hotz and Walczyk 2013). The origin of this difference is unclear. The impact of the environmental context on $\mathrm{Zn}$ isotope compositions of a food web is also unclear, albeit suspected (Jaouen et al. 2013b; Jaouen et al. 2016a, 2016b). Consequently, the application of non-traditional analyses for dietary reconstruction will require systematic analyses of the associated fauna or soils. 


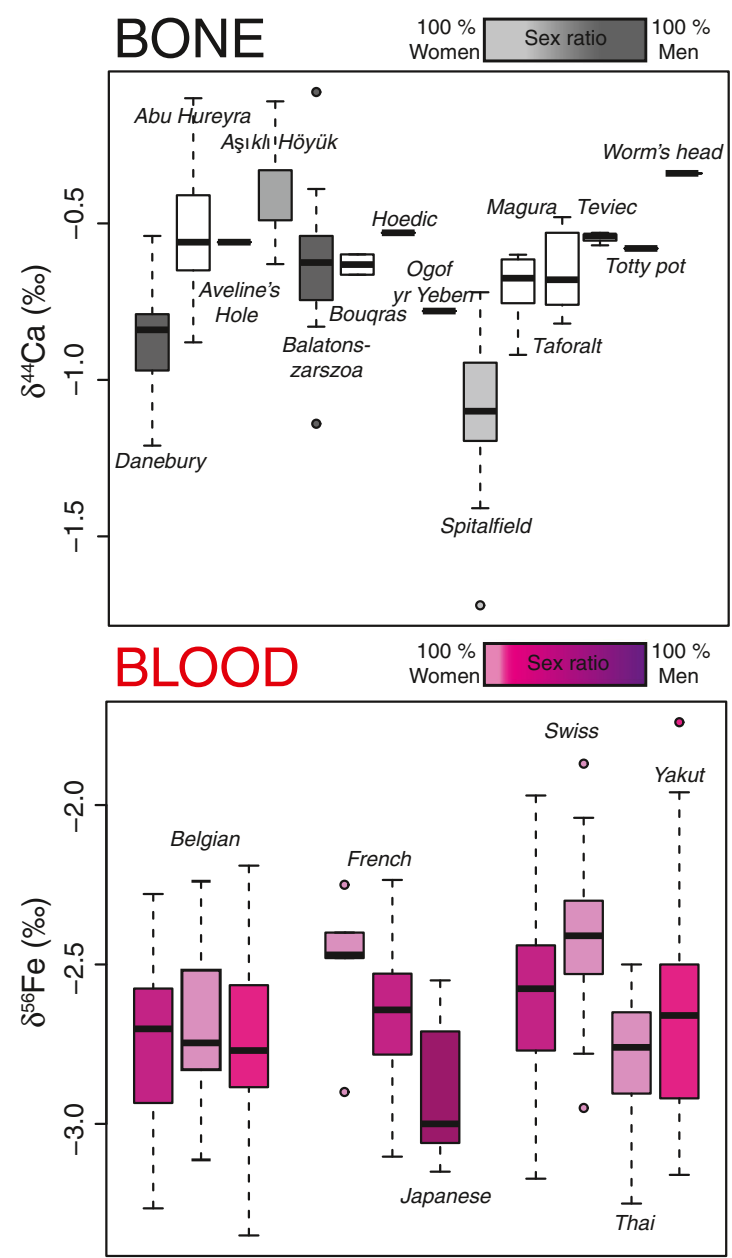

Fig. 4 Range of isotope values observed in bones (for $\mathrm{Ca}$ isotopes), whole blood (for $\mathrm{Cu}, \mathrm{Fe}$ and $\mathrm{Zn}$ isotopes) or red blood cells ( $\mathrm{Fe}, \mathrm{Zn}$ isotopes). Data come from Reynard et al. (2011, 2013) (Ca isotopes), Van Heghe et al. (2012, 2014), Larner et al. (2015), Albarède et al. (2011) and Jaouen et al. (2013a) (Cu isotopes), Van Heghe et al. (2012, 2013, 2014), Albarède et al. (2011), Jaouen et al. (2013a), Ohno et al.

\section{Metabolism and non-traditional isotope compositions}

Elements with non-traditional isotopic composition can play a central role in human metabolism. Calcium is the main constituent of bones and teeth, and $\mathrm{Mg}$ contributes to their mineralization. Both elements play a crucial role in many important physiological functions such as muscular contraction and neurotransmission (Nadler and Rude 1995). Iron and $\mathrm{Cu}$ are involved in bone formation and maintenance, electron and oxygen transfer and erythropoiesis amongst other things (Arredondo and Núñez 2005). Zinc is present in more than 300 metalloproteins, most of which have enzymatic or structural properties (Cousins 1985). Being essential nutrients, the concentrations of these elements are finely regulated by the organism, if only to remain in the interval defined by deficiency and toxicity levels. Conversely, isotope abundances a priori do not undergo regulation mechanisms in mammalian bodies. They can therefore provide additional physiological

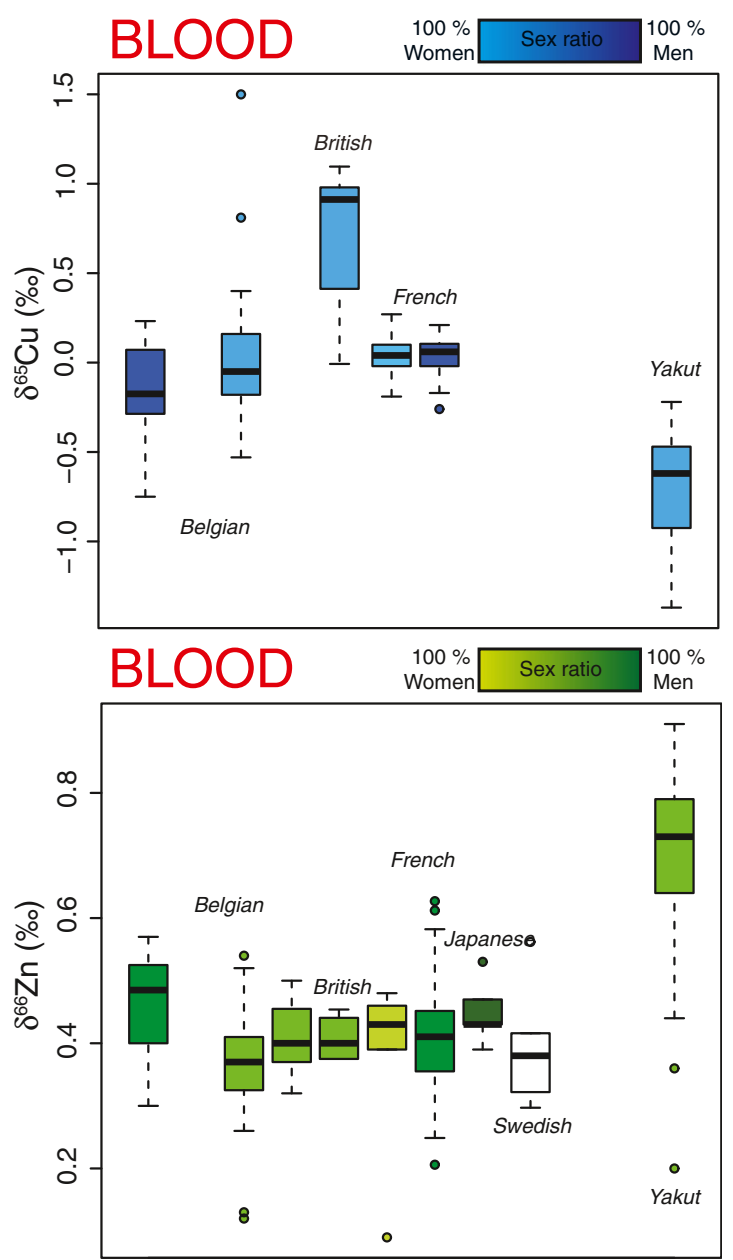

(2005), Walczyk and von Blanckenburg (2002) and Hotz and Walczyk (2013) (Fe isotopes) and Van Heghe et al. (2012, 2013, 2014), CostasRodríguez et al. (2014), Larner et al. (2015), Albarède et al. (2011), Jaouen et al. (2013a), Ohno et al. (2004) and Stenberg et al. (2005) (Zn isotopes). Delta values are expressed relative to NIST 915a, IRMM-014, NIST 976 and JMC-Lyon 3-0749 standards, respectively

information on elemental metabolism under normal or pathological conditions.

\section{Metabolic dysregulations}

Non-traditional isotopes have recently been the subjects of many studies because of their potential to trace metabolic diseases such as hemochromatosis (Krayenbuehl et al. 2005; Stenberg et al. 2005, Walczyk and von Blanckenburg 2005), iron deficiency (Van Heghe et al. 2013), Wilson disease (Aramendía et al. 2013; Resano et al. 2013), cancers (Balter et al. 2015; Larner et al. 2015; Télouk et al. 2015; Bondanese et al. 2016; Chamel et al. 2016) or bone mineral balance (Skulan et al. 2007; Heuser and Eisenhauer 2010; Morgan et al. 2011; Anbar et al. 2013). The potential of these isotopes as a new diagnostic tool in biomedicine has recently been fully described in four reviews (Albarède et al. 2016; 
Costas-Rodríguez et al. 2016; Heuser 2016; Larner 2016). Even if it has not yet been investigated, mineralized tissues are likely to record isotopic signatures of these pathologies. Indeed, it has already been shown that they can trace the $\mathrm{Fe}, \mathrm{Cu}$ and $\mathrm{Zn}$ isotopic signatures of sex (Jaouen et al. 2012) and diet (Jaouen et al. 2016a, 2016b), previously observed in blood (Walczyk and von Blanckenburg 2002; Albarède et al. 2011; Costas-Rodríguez et al. 2014). Such identification of diseases would open up a new field in palaeoepidemiology and would have the potential to trace the emergence of specific metabolic diseases.

\section{Sex-dependent isotopic differences}

The first study published on Fe isotopes in human blood highlighted different isotopic compositions between men and women (Walczyk and von Blanckenburg 2002). Later, it was shown that these differences also exist for $\mathrm{Cu}$ isotopes but not for $\mathrm{Zn}$ isotopes (Albarède et al. 2011) and can be seen in human bones (Jaouen et al. 2012). These sex isotope differences could be due to a metabolic response to the menstrual iron losses: the mechanism involved could be the higher $\mathrm{Fe}$ intestinal absorption of women, the mobilization of liver $\mathrm{Fe}$ stores, which are enriched in heavy Fe isotopes, or a combination of the two (Hotz et al. 2012; Jaouen and Balter 2014). As a consequence, the sex isotope differences disappear after menopause (Jaouen and Balter 2014; Van Heghe et al. 2014), following different timelines on the turnover of the element: a couple of months for $\mathrm{Cu}$ and several years for $\mathrm{Fe}$. Surprisingly, the study of a Yakut population showed no differences between pre- and post-menopausal women for $\mathrm{Fe}$ and the opposite trend for $\mathrm{Cu}$ compared to European populations (Jaouen et al. 2013a). This unique observation remains unexplained. Interestingly, an isotopic difference between sexes has also been highlighted for $\mathrm{Ca}$ isotopes in sheep bones

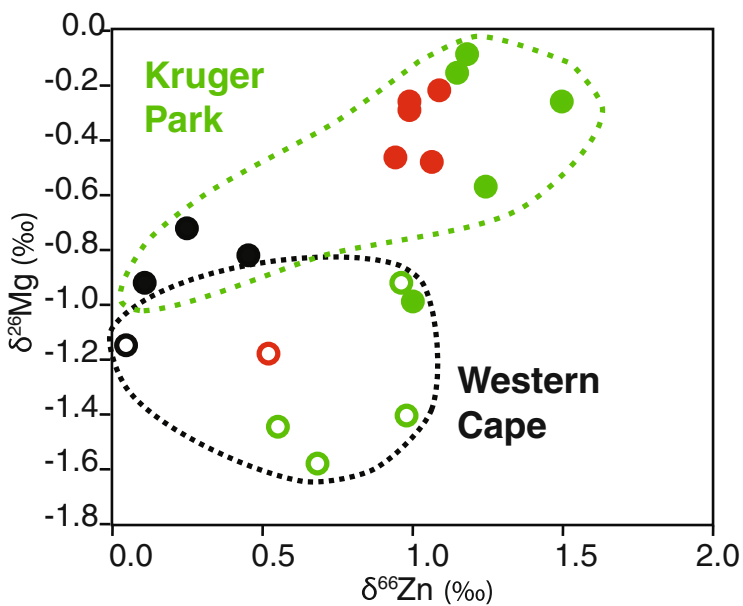

Fig. 5 Correlation between $\delta^{66} \mathrm{Zn}$ values from Jaouen et al. (2013b) to $\delta^{26} \mathrm{Mg}$ and $\mathrm{Sr} / \mathrm{Ca}$ ratios from Martin et al. (2014). The two studies were performed on several identical specimens coming from two South
(Reynard et al. 2010). The explanation is that the females suckled their lambs, thus altering their $\mathrm{Ca}$ bone balance. This pattern was also observed in human bones, though it was not significant. Besides, the number of times a woman has given birth is not correlated to the Ca isotope composition of her bones (Reynard et al. 2013). Further investigations did not confirm this trend, but the sex ratios of the studied populations were often imbalanced (Fig. 4).

\section{Perspectives in non-traditional isotope studies}

\section{Comparison to classic isotope tracers in archaeology}

Non-traditional isotopes are likely to provide complementary information to classic isotopes or other chemical tracers, which could help access high-resolution information on diet and mobility of past populations. Melin et al. (2014), Martin et al. (2015b) and Jaouen et al. (2016b) showed that the combination of $\mathrm{Ca}, \mathrm{Mg}$ or $\mathrm{Zn}$ (respectively) with $\mathrm{C}$ isotopes in bioapatite could work in a similar way to $\mathrm{N}$ and $\mathrm{C}$ isotopes when the collagen is not preserved. Thus, information on the diet of fossil remains could be retrieved in dental enamel, which can be preserved for several millions of years, as shown by $\mathrm{Sr}$ radiogenic isotope studies in South African early hominins (Copeland et al. 2011, Balter et al. 2012) and even Mesozoïc animals (e.g. Martin et al. 2016). This could also apply to $\mathrm{Zn}$, which is as concentrated as $\mathrm{Sr}$ in teeth. Knowing that mobility can generate additional variation to diet on nontraditional isotopic compositions, it would be interesting to analyse whether individuals are locals or not, using Sr radiogenic isotopic ratios. In addition, Martin et al. (2014, 2015b) showed the potential of combining $\mathrm{Mg}$ isotopes to trace elements studies, such as $\mathrm{Sr} / \mathrm{Ca}$ ratios, which is related to the trophic level via the process of biopurification. As they

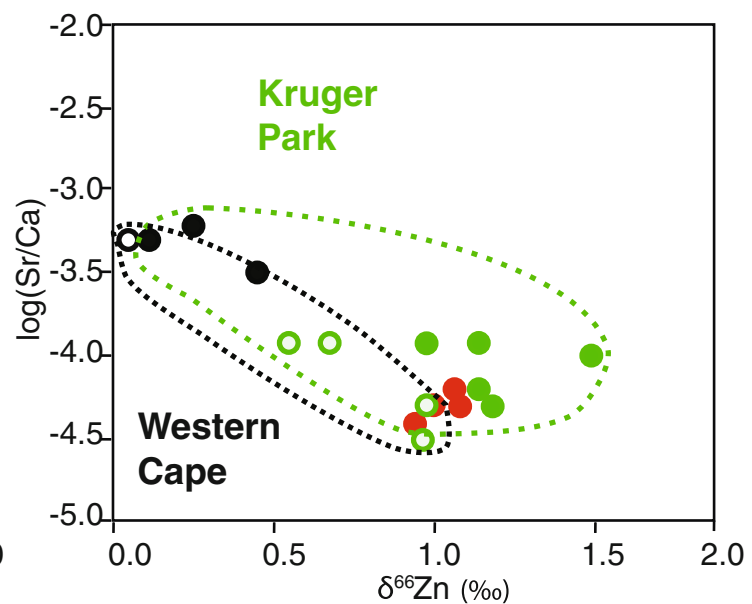

African sites: Western Cape (empty markers) and Kruger Park (plain markers). Red symbols correspond to carnivores, green to herbivores and black to plants 
worked on several specimens that we previously analysed for $\mathrm{Zn}$ isotopes (Jaouen et al. 2013b), we take the opportunity of this review to compare the $\delta^{66} \mathrm{Zn}$ values, the $\delta^{26} \mathrm{Mg}$ values and $\mathrm{Sr} / \mathrm{Ca}$ ratio obtained by Martin et al. (2014). Magnesium isotopes seem to be more affected by the environmental context than $\mathrm{Zn}$ isotopes (Fig. 5), but within Kruger Park, some of the $\mathrm{Zn}$ and $\mathrm{Mg}$ isotopic values correlate, which might indicate that both tracers are similarly responding to the trophic level effect. The fact that both non-traditional tracers also correlate with $\mathrm{Sr} /$ $\mathrm{Ca}$ ratios could be additional evidence in favour of this conclusion (Fig. 5, Martin et al. 2014). However, in the case of $\mathrm{Zn}$, the sample size is low (Fig. 5). Further work is therefore needed to confirm this pattern.

\section{Other candidates for non-traditional isotope archaeological tracers}

Some other elements have been investigated in mammalian tissues but not yet in an archaeological perspective. Mercury isotopes have been analysed in human hair and used to trace the origin of mercury in the diet (gold mining) but also the geographic origin of the fish eaten (freshwater, coastal or plain ocean) (Laffont et al. 2009, 2011; Li et al. 2014). Lithium isotopes have not yet been measured in human tissues, but it has been shown that these isotopes fractionate between the different organs of mammals (Balter and Vigier 2014), which is promising for their use as a future new dietary tracer. Analytical protocols for non-traditional isotope compositions of other elements (e.g. cadmium, silicon, selenium) have been developed in biogeochemistry but have not yet been applied to mammalian tissues.

\section{Concluding remarks}

Non-traditional isotopes have demonstrated their promising potential for archaeology, especially because they can be used to trace the diet and mobility of ancient hominins, even when collagen is not preserved. The main information provided by these tracers is summarized in Table 2. However, this field in still in its infancy and further work is needed to calibrate the tracers and to start routinely using them in the archaeological sciences. The term "non-traditional" will probably soon be outdated. It might therefore be interesting to rename these isotopes in the future, possibly according to their group in the periodic classification.

Acknowledgments Open access funding provided by Max Planck Society. We thank Helen Williams, Pierre Clairambault, Carrie Wright, Esther Plomp, Théo Tacail, Thomas Tütken, Vincent Balter and Michael P. Richards for helpful discussions. We are very grateful to the very helpful comments of Jérémy Martin and three anonymous reviewers, as well as to Angela Perri for editing the English. KJ and MLP acknowledge salary support from the Max Planck Society and an ERC Starting Grant (Habitable Planet; 306655), respectively.
Open Access This article is distributed under the terms of the Creative Commons Attribution 4.0 International License (http:// creativecommons.org/licenses/by/4.0/), which permits unrestricted use, distribution, and reproduction in any medium, provided you give appropriate credit to the original author(s) and the source, provide a link to the Creative Commons license, and indicate if changes were made.

\section{References}

Albarède F (1996) Introduction to geochemical modeling. Cambridge University Press

Albarède $F$ (2015) Metal stable isotopes in the human body: a tribute of geochemistry to medicine. Elements 11:265-269. doi:10.2113/gselements.11.4.265

Albarède F, Beard B (2004) Analytical methods for nontraditional isotopes. Rev Mineral Geochem 55:113-152. doi:10.2138/gsrmg.55.1.113

Albarède F, Dedaulty A-M, Blichert-Toft J (2012) A geological perspective on the use of $\mathrm{Pb}$ isotopes in archaeometry. Archaeometry 54:853-867

Albarède F, Télouk P, Balter V, Bondanese VP, Albalat E, Oger P, Fujii T (2016) Medical applications of $\mathrm{Cu}, \mathrm{Zn}$, and $\mathrm{S}$ isotope effects. Metallomics. doi:10.1039/C5MT00316D

Albarède F, Telouk P, Lamboux A, Jaouen K, Balter V (2011) Isotopic evidence of unaccounted for $\mathrm{Fe}$ and $\mathrm{Cu}$ erythropoietic pathways. Metallomics 3:926-933. doi:10.1039/C1MT00025J

Anbar A, Skulan J, Gordon G, Morgan J (2013) Isotopic biomarkers for rapid assessment of bone mineral balance in biomedical applications

Anbar AD, Rouxel O (2007) Metal stable isotopes in paleoceanography. Annu Rev Earth Planet Sci 35:717-746

Anoshkina Y, Costas-Rodríguez M, Vanhaecke F (2015) High-precision Fe isotopic analysis of whole blood for biomedical purposes without prior isolation of the target element. J Anal At Spectrom 30:1816-1821

Aramendía M, Rello L, Resano M, Vanhaecke F (2013) Isotopic analysis of $\mathrm{Cu}$ in serum samples for diagnosis of Wilson's disease: a pilot study. J Anal Spectrom 28:675-681

Arredondo M, Núñez MT (2005) Iron and copper metabolism. Mol Asp Med 26:313-327. doi:10.1016/j.mam.2005.07.010

Aucour AM, Pichat S, Macnair MR, Oger P (2011) Fractionation of stable zinc isotopes in the zinc hyperaccumulator Arabidopsis halleri and nonaccumulator Arabidopsis petraea. Environ Sci Technol 45: 9212-9217. doi:10.1021/es200874x

Balliana E, Aramendía M, Resano M, Barbante C, Vanhaecke F (2013) Copper and tin isotopic analysis of ancient bronzes for archaeological investigation: development and validation of a suitable analytical methodology. Anal Bioanal Chem 405(9):2973-2986

Balter V, Simon L (2006) Diet and behavior of the Saint-Cesaire Neanderthal inferred from biogeochemical data inversion. J Hum Evol 51:329-338

Balter V, Vigier N (2014) Natural variations of lithium isotopes in a mammalian model. Metallomics 6:582-586

Balter V, Braga J, Télouk P, Thackeray JF (2012) Evidence for dietary change but not landscape use in South African early hominins. Nature 489:558-560

Balter V, da Costa AN, Bondanese VP, Jaouen K, Lamboux A, Sangrajrang S, Vincent N, Fourel F, Télouk P, Gigou M, Lécuyer C, Srivatanakul P, Bréchot C, Albarède F, Hainauth P (2015) Natural variations of copper and sulfur stable isotopes in blood of hepatocellular carcinoma patients. Proc Natl Acad Sci 112:982-985

Balter V, Lamboux A, Zazzo A et al (2013) Contrasting Cu, Fe, and Zn isotopic patterns in organs and body fluids of mice and sheep, with emphasis on cellular fractionation. Metallomics 5:1470-1482 
Balter V, Zazzo A, Moloney AP et al (2010) Bodily variability of zinc natural isotope abundances in sheep. Rapid Commun Mass Spectrom 24:605-612. doi:10.1002/rcm.4425

Baron S, Coustures M-P (2015) Apports et limites des méthodes isotopiques pour restituer la circulation des métaux aux périodes anciennes. Nouv Archéologie:35-39

Beard BL, Johnson CM (1999) High precision iron isotope measurements of terrestrial and lunar materials. Geochim Cosmochim Acta 63: 1653-1660. doi:10.1016/S0016-7037(99)00089-7

Beasley MM, Bartelink EJ, Taylor L, Miller RM (2014) Comparison of transmission FTIR, ATR, and DRIFT spectra: implications for assessment of bone bioapatite diagenesis. J Archaeol Sci 46:16-22

Belshaw NS, Zhu XK, Guo Y, O’Nions RK (2000) High precision measurement of iron isotopes by plasma source mass spectrometry. Int J Mass Spectrom 197:191-195. doi:10.1016/S1387-3806(99)00245-6

Bentley RA (2006) Strontium isotopes from the earth to the archaeological skeleton: a review. J Archaeol Method Theory 13:135-187. doi:10.1007/s10816-006-9009-x

Bigeleisen J (1965) Chemistry of isotopes isotope chemistry has opened new areas of chemical physics, geochemistry, and molecular biology. Science 147:463-471

Black JR, Epstein E, Rains WD et al (2008) Magnesium-isotope fractionation during plant growth. Environ Sci Technol 42:7831-7836

Bocherens H, Drucker D (2003) Trophic level isotopic enrichment of carbon and nitrogen in bone collagen: case studies from recent and ancient terrestrial ecosystems. Int J Osteoarchaeol 13:46-53. doi:10.1002/oa.662

Bondanese VP, Lamboux A, Simon M, Lafont JE, Albalat E, Pichat S, Vanacker J-M, Telouk P, Balter V, Oger P, Albarède F (2016) Hypoxia induces copper stable isotope fractionation in hepatocellular carcinoma, in a HIF-independent manner. Metallomics doi. doi:10.1039/C6MT00102E

Chamel G, Gourlan AT, Télouk P, Sayag D, Milliard V, Loiseau C, Simon M, Buff S, Ponce F (2016) Retrospective evaluation of blood copper stable isotopes ratio $65 \mathrm{Cu} / 63 \mathrm{Cu}$ as a biomarker of cancer in dogs. Vet Comp Oncol. doi:10.1111/vco.12273

Chiaradia M, Gallay A, Todt W (2003) Different contamination styles of prehistoric human teeth at a Swiss necropolis (Sion, Valais) inferred from lead and strontium isotopes. Appl Geochem 18:353-370

Chu NC, Henderson GM, Belshaw NS, Hedges REM (2006) Establishing the potential of $\mathrm{Ca}$ isotopes as proxy for consumption of dairy products. Appl Geochem 21:1656-1667

Clementz MT, Holden P, Koch PL (2003) Are calcium isotopes a reliable monitor of trophic level in marine settings? Int J Osteoarchaeol 13(1-2):29-36

Copeland SR, Sponheimer M, de Ruiter DJ, Lee-Thorp JA, Codron D, le Roux PJ, Grimes V, Richards MP (2011) Strontium isotope evidence for landscape use by early hominins. Nature 474:76-78. doi:10.1038/nature10149

Copeland SR, Sponheimer M, le Roux PJ, Grimes V, Lee-Thorp JA, de Ruiter DJ, Richards MP (2008) Strontium isotope ratios (87Sr/86Sr) of tooth enamel: a comparison of solution and laser ablation multicollector inductively coupled plasma mass spectrometry methods. Rapid Commun Mass Spectrom 22:3187-3194

Costas-Rodríguez M, Delanghe J, Vanhaecke F (2016) High-precision isotopic analysis of essential mineral elements in biomedicine: natural isotope ratio variations as potential diagnostic and/or prognostic markers. TrAC Trends Anal Chem 76:182-193. doi:10.1016/j. trac.2015.10.008

Costas-Rodríguez M, Van Heghe L, Vanhaecke F (2014) Evidence for a possible dietary effect on the isotopic composition of $\mathrm{Zn}$ in blood via isotopic analysis of food products by multi-collector ICP-mass spectrometry. Metallomics 6:139-146

Cousins RJ (1985) Absorption, transport, and hepatic metabolism of copper and zinc: special reference to metallothionein and ceruloplasmin. Physiol Rev 65:238-309
Dansgaard W (1964) Stable isotopes in precipitation. Tellus 16:436-468. doi:10.1111/j.2153-3490.1964.tb00181.x

Delile H, Blichert-Toft J, Goiran J-P, Keay S, Albarède F (2014) Lead in ancient Rome's city waters. Proc Natl Acad Sci 111:6594-6599

DeNiro MJ, Epstein S (1978) Influence of diet on the distribution of carbon isotopes in animals. Geochim Cosmochim Acta 42:495-506

DeNiro MJ, Epstein S (1981) Influence of diet on the distribution of nitrogen isotopes in animals. Geochim Cosmochim Acta 45:341-351

DePaolo DJ (2004) Calcium isotopic variations produced by biological, kinetic, radiogenic and nucleosynthetic processes. Rev Mineral Geochem 55(1):255-288

Desaulty A-M, Telouk P, Albalat E, Albarède F (2011) Isotopic Ag-Cu$\mathrm{Pb}$ record of silver circulation through 16th-eighteenth century Spain. Proc Natl Acad Sci 108:9002-9007

Dudd SN, Evershed RP, Gibson AM (1999) Evidence for varying patterns of exploitation of animal products in different prehistoric pottery traditions based on lipids preserved in surface and absorbed residues. J Archaeol Sci 26:1473-1482

Ehleringer JR, Bowen GJ, Chesson LA, West AG, Podlesak DW, Cerling TE (2008) Hydrogen and oxygen isotope ratios in human hair are related to geography. Proc Natl Acad Sci 105:2788-2793

Evans JA, Chenery CA, Fitzpatrick AP (2006) Bronze age childhood migration of individuals near stonhenge revealed by strontium, and oxygen isotope tooth enamel analysis. Archaeometry 48:309-321

Firestone RB, Shirley VS (1998) Table of isotopes, 2 volume set. Table Isot 2 Vol Set Richard B Firestone Va Shirley Ed Pp 3168 ISBN 0-471-33056-6 Wiley-VCH Dec 19983168.

Fraser I, Meier-Augenstein W (2007) Stable 2H isotope analysis of modern-day human hair and nails can aid forensic human identification. Rapid Commun Mass Spectrom 21:3279-3285

Fuller BT, Fuller JL, Harris DA, Hedges RE (2006) Detection of breastfeeding and weaning in modern human infants with carbon and nitrogen stable isotope ratios. Am J Phys Anthropol 129:279-293

Galy A, Belshaw NS, Halicz L, O’Nions RK (2001) High-precision measurement of magnesium isotopes by multiple-collector inductively coupled plasma mass spectrometry. Int J Mass Spectrom 208:89-98. doi:10.1016/S1387-3806(01)00380-3

Gehrke GE, Blum JD, Slotton DG, Greenfield BK (2011) Mercury isotopes link mercury in San Francisco Bay forage fish to surface sediments. Environ Sci Technol 45:1264-1270. doi:10.1021/es103053y

Gosz JR, Brookins DG, Moore DI (1983) Using strontium isotope ratios to estimate inputs to ecosystems. Bioscience 33:23-30. doi: $10.2307 / 1309240$

Grayson DK (1984) Quantitative zooarchaeology: topics in the analysis of archaeological faunas. Academic Press

Gross KA, Berndt CC (2002) Biomedical application of apatites. Rev Mineral Geochem 48:631-672

Guelke M, von Blanckenburg F (2007) Fractionation of stable iron isotopes in higher plants. Environ Sci Technol 41:1896-1901

Halicz L, Galy A, Belshawa NS, O’Nionsa RK (1999) High-precision measurement of calcium isotopes in carbonates and related materials by multiple collector inductively coupled plasma mass spectrometry (MC-ICP-MS). J Anal At Spectrom 14:1835-1838

Hartman G, Richards M (2014) Mapping and defining sources of variability in bioavailable strontium isotope ratios in the Eastern Mediterranean. Geochim Cosmochim Acta 126:250-264. doi:10.1016/j.gca.2013.11.015

Hedges RE (2002) Bone diagenesis: an overview of processes. Archaeometry 44:319-328

Hedges RE, Reynard LM (2007) Nitrogen isotopes and the trophic level of humans in archaeology. J Archaeol Sci 34(8):1240-1251

Hedges REM, Clement JG, Thomas CDL, O'Connell TC (2007) Collagen turnover in the adult femoral mid-shaft: modeled from anthropogenic radiocarbon tracer measurements. Am J Phys Anthropol 133:808-816 
Henry AG, Piperno DR (2008) Using plant microfossils from dental calculus to recover human diet: a case study from Tell al-Raqā'i, Syria. J Archaeol Sci 35:1943-1950

Herrscher E (2013) Détection isotopique des modalités d'allaitement et de sevrage à partir des ossements archéologiques.

Heuser A (2016). Biomedical application of Ca stable isotopes. In Calcium stable isotope geochemistry (pp. 247-260). Springer Berlin Heidelberg.

Heuser A, Eisenhauer A (2010) A pilot study on the use of natural calcium isotope $(44 \mathrm{Ca} / 40 \mathrm{Ca})$ fractionation in urine as a proxy for the human body calcium balance. Bone 46:889-896. doi:10.1016/j. bone.2009.11.037

Heuser A, Tütken T, Gussone N, Galer SJ (2011) Calcium isotopes in fossil bones and teeth - diagenetic versus biogenic origin. Geochim Cosmochim Acta 75:3419-3433

Hindshaw RS, Reynolds BC, Wiederhold JG, Kiczka M, Kretzschmar R, Bourdon B (2013) Calcium isotope fractionation in alpine plants. Biogeochemistry 112:373-388

Holobinko A, Meier-Augenstein W, Kemp HF, Prowse T, Ford SM (2011) 2H stable isotope analysis of human tooth enamel: a new tool for forensic human provenancing? Rapid Commun Mass Spectrom 25:910-916

Hoppe KA, Koch PL, Furutani TT (2003) Assessing the preservation of biogenic strontium in fossil bones and tooth enamel. Int $\mathrm{J}$ Osteoarchaeol 13:20-28. doi:10.1002/oa.663

Hotz K, Krayenbuehl PA, Walczyk T (2012) Mobilization of storage iron is reflected in the iron isotopic composition of blood in humans. J Biol Inorg Chem 1-9.

Hotz K, Walczyk T (2013) Natural iron isotopic composition of blood is an indicator of dietary iron absorption efficiency in humans. JBIC Journal of Biological Inorganic Chemistry 18(1):1-7

Jaouen K, Balter V (2014) Menopause effect on blood Fe and $\mathrm{Cu}$ isotope compositions. Am J Phys Anthropol 153:280-285. doi:10.1002/ajpa.22430

Jaouen K, Gibert M, Lamboux A, Télouk P, Fourel F, Albarède F, Crubézy E, Alekseev AN, Balter V (2013a) Is aging recorded in blood $\mathrm{Cu}$ and $\mathrm{Zn}$ isotope compositions? Metallomics 5:10161024. doi: $10.1039 / \mathrm{C} 3 \mathrm{MT} 00085 \mathrm{~K}$

Jaouen K, Pons M-L, Balter V (2013b) Iron, copper and zinc isotopic fractionation up mammal trophic chains. Earth Planet Sci Lett 374: 164-172. doi:10.1016/j.epsl.2013.05.037

Jaouen K, Balter V, Herrscher E, Lamboux A, Télouk P, Albarède F (2012) $\mathrm{Fe}$ and $\mathrm{Cu}$ stable isotopes in archeological human bones and their relationship to sex. Am J Phys Anthropol 148:334-340. doi:10.1002/ajpa.22053

Jaouen K, Beasley M, Schoeninger MJ, Hublin J-J, Richards MP (2016a) Zinc isotope ratios of bones and teeth as new dietary indicators: results from a modern food web (Koobi Fora, Kenya). Sci Rep 6

Jaouen K, Szpak P, Richards MP (2016b) Zinc isotope ratios as indicators of diet and trophic level in arctic marine mammals. PLoS One 11(3)

Johnson CM, Beard BL (1999) Correction of instrumentally produced mass fractionation during isotopic analysis of $\mathrm{Fe}$ by thermal ionization mass spectrometry. Int J Mass Spectrom 193:87-99

Jouvin D, Weiss DJ, Mason TFM, Bravin MN, Louvat P, Zhao F, Ferec F, Hinsinger P, Benedetti MF (2012) Stable isotopes of $\mathrm{Cu}$ and $\mathrm{Zn}$ in higher plants: evidence for $\mathrm{Cu}$ reduction at the root surface and two conceptual models for isotopic fractionation processes. Environ Sci Technol 46:2652-2660

Kelly JF (2000) Stable isotopes of carbon and nitrogen in the study of avian and mammalian trophic ecology. Can J Zool 78:1-27

Knudson KJ, Williams HM, Buikstra JE, Tomczak PD, Gordon GW, Anbar AD (2010) Introducing $888 / 86 \mathrm{Sr}$ analysis in archaeology: a demonstration of the utility of strontium isotope fractionation in paleodietary studies. J Archaeol Sci 37:2352-2364. doi:10.1016/j. jas.2010.04.009
Kohn MJ, Schoeninger MJ, Barker WW (1999) Altered states: effects of diagenesis on fossil tooth chemistry. Geochim Cosmochim Acta 63: $2737-2747$

Krayenbuehl PA, Walczyk T, Schoenberg R, von Blanckenburg F, Schulthess G (2005) Hereditary hemochromatosis is reflected in the iron isotope composition of blood. Blood 105:3812-3816

Laffont L, Sonke JE, Maurice L, Hintelmann H, Pouilly M, Sánchez Bacarreza Y, Perez T, Behra B (2009) Anomalous mercury isotopic compositions of fish and human hair in the Bolivian Amazon. Environ Sci Technol 43:8985-8990. doi:10.1021/es9019518

Laffont L, Sonke JE, Maurice L, Monrroy SL, Chincheros J, Amouroux D, Behra P (2011) Hg speciation and stable isotope signatures in human hair as a tracer for dietary and occupational exposure to mercury. Environ Sci Technol 45:9910-9916. doi:10.1021/es202353m

Larner F (2016) Can we use high precision metal isotope analysis to improve our understanding of cancer? Anal Bioanal Chem 408:345-349

Larner F, Sampson B, Rehkämper M, Weiss DJ, Dainty JR, O'Riordan S, Panetta T, Bain PG (2013) High precision isotope measurements reveal poor control of copper metabolism in parkinsonism. Metallomics 5:125. doi:10.1039/c3mt20238k

Larner F, Woodley LN, Shousha S, Moyes A, Humphreys-Williams E, Strekopytov S, Halliday AN, Rehkämper M, Coombes RC (2015) Zinc isotopic compositions of breast cancer tissue. Metallomics 7: 107-112

Lauwens S, Costas-Rodríguez M, Van Vlierberghe H, Vanhaecke F (2016) $\mathrm{Cu}$ isotopic signature in blood serum of liver transplant patients: a follow-up study. Scientific Reports 6

Lee-Thorp J, Sponheimer M (2003) Three case studies used to reassess the reliability of fossil bone and enamel isotope signals for paleodietary studies. J Anthropol Archaeol 22:208-216. doi:10.1016/S0278-4165(03)00035-7

Lee-Thorp J, Sponheimer M (2006) Contributions of biogeochemistry to understanding hominin dietary ecology. Am J Phys Anthropol 131: $131-148$

Lee-Thorp JA, van der Merwe NJ (1991) Aspects of the chemistry of modern and fossil biological apatites. J Archaeol Sci 18:343-354. doi:10.1016/0305-4403(91)90070-6

Li M, Sherman LS, Blum JD, Grandjean P, Mikkelsen B, Weihe P, Sunderland EM, Shine JM (2014) Assessing sources of human methylmercury exposure using stable mercury isotopes. Environ Sci Technol 48:8800-8806

Li Q, Thirlwall M, Müller W (2016) Ca isotopic analysis of laser-cut microsamples of (bio)apatite without chemical purification. Chem Geol 422:1-12. doi:10.1016/j.chemgeo.2015.12.007

Longinelli A (1984) Oxygen isotopes in mammal bone phosphate: a new tool for paleohydrological and paleoclimatological research? Geochim Cosmochim Acta 48:385-390. doi:10.1016/0016-7037(84)90259-X

Lönnerdal B (2000) Dietary factors influencing zinc absorption. J Nutr 130:1378S-1383S

Maréchal CN, Télouk P, Albarède F (1999) Precise analysis of copper and zinc isotopic compositions by plasma-source mass spectrometry. Chem Geol 156:251-273

Marschner H, Römheld V (1994) Strategies of plants for acquisition of iron. Plant Soil 165(2):261-274

Martin JE, Deesri U, Liard R, Wattanapituksakul A, Suteethorn S, Lauprasert K, Tong H, Buffetaut E, Suteethorn V, Suan G, Telouk $\mathrm{P}$, Balter V (2016) Strontium isotopes and the long-term residency of thalattosuchians in the freshwater environment. Paleobiology 42: $143-156$

Martin JE, Tacail T, Adnet S, Girard C, Balter V (2015a) Calcium isotopes reveal the trophic position of extant and fossil elasmobranchs. Chem Geol 415:118-125

Martin JE, Vance D, Balter V (2014) Natural variation of magnesium isotopes in mammal bones and teeth from two South African trophic chains. Geochim Cosmochim Acta 130:12-20 
Martin JE, Vance D, Balter V (2015b) Magnesium stable isotope ecology using mammal tooth enamel. Proc Natl Acad Sci 112:430-435

Martínez-García MJ, Moreno JM, Moreno-Clavel J, Vergara N, GarcíaSánchez A, Guillamón A, Portíc M, Moreno-Grau S (2005) Heavy metals in human bones in different historical epochs. Sci Total Environ 348:51-72

McConnaughey T, McRoy CP (1979) Food-web structure and the fractionation of carbon isotopes in the Bering Sea. Mar Biol 53:257262. doi:10.1007/BF00952434

Melin AD, Crowley BE, Brown ST, Crowley WPV, Moritz GL, Yu Y, Bernard H, DePaolo DJ, Jacobson AD, Dominy NJ (2014) Technical note: calcium and carbon stable isotope ratios as paleodietary indicators. Am J Phys Anthropol 154:633-643. doi:10.1002/ajpa.22530

Minagawa M, Wada E (1984) Stepwise enrichment of ${ }^{15} \mathrm{~N}$ along food chains: further evidence and the relation between $\delta^{15} \mathrm{~N}$ and animal age. Geochim et cosmochim acta 48(5):1135-1140

Montgomery J, Budd P, Evans J (2000) Reconstructing the lifetime movements of ancient people: a Neolithic case study from southern England. Eur J Archaeol 3:370-385. doi:10.1179/146195700807860828

Morgan JL, Skulan JL, Gordon GW et al (2012) Rapidly assessing changes in bone mineral balance using natural stable calcium isotopes. Proc Natl Acad Sci 109:9989-9994

Morgan JLL, Gordon GW, Arrua RC, Skulan JL, Anbar AD, Bullen TD (2011) High-precision measurement of variations in calcium isotope ratios in urine by multiple collector inductively coupled plasma mass spectrometry. Anal Chem 83:6956-6962. doi:10.1021/ac200361t

Moynier F, Albarede F, Herzog GF (2006) Isotopic composition of zinc, copper, and iron in lunar samples. Geochim Cosmochim Acta 70: 6103-6117

Moynier F, Fujii T, Shaw AS, Le Borgne M (2013) Heterogeneous distribution of natural zinc isotopes in mice. Metallomics 5:693-699

Moynier F, Pichat S, Pons ML, Fike D, Balter V, Albarède F (2009) Isotopic fractionation and transport mechanisms of $\mathrm{Zn}$ in plants. Chem Geol 267:125-130

Nadler JL, Rude RK (1995) Disorders of magnesium metabolism. Endocrinol Metab Clin N Am 24:623-641

Nehlich O (2015) The application of sulphur isotope analyses in archaeological research: a review. Earth-Sci Rev 142:1-17

Nehlich O, Fuller BT, Jay M, Mora A, Nicholson RA, Smith CI, Richards MP (2011) Application of sulphur isotope ratios to examine weaning patterns and freshwater fish consumption in Roman Oxfordshire, UK. Geochim Cosmochim Acta 75:4963-4977

O’Brien DM, Wooller MJ (2007) Tracking human travel using stable oxygen and hydrogen isotope analyses of hair and urine. Rapid Commun Mass Spectrom 21:2422-2430

Ohno T, Shinohara A, Chiba M, Hirata T (2005) Precise Zn isotopic ratio measurements of human red blood cell and hair samples by multiple collector-ICP-mass spectrometry. Anal Sci 21:425-428

Ohno T, Shinohara A, Kohge I, Chiba M, Hirata T (2004) Isotopic analysis of $\mathrm{Fe}$ in human red blood cells by multiple collector-ICP-mass spectrometry. Anal Sci 20:617-621

Pate FD (1994) Bone chemistry and paleodiet. J Archaeol Method Theory 1:161-209. doi:10.1007/BF02231415

Pestle WJ, Colvard M (2012) Bone collagen preservation in the tropics: a case study from ancient Puerto Rico. J Archaeol Sci 39:2079-2090. doi:10.1016/j.jas.2012.03.008

Price TD, Blitz J, Burton J, Ezzo JA (1992) Diagenesis in prehistoric bone: problems and solutions. J Archaeol Sci 19:513-529

Pucéat E, Reynard B, Lécuyer C (2004) Can crystallinity be used to determine the degree of chemical alteration of biogenic apatites? Chem Geol 205:83-97

Resano M, Aramendía M, Rello L, Calvo ML, Bérail S, Pécheyran C (2013) Direct determination of $\mathrm{Cu}$ isotope ratios in dried urine spots by means of fs-LA-MC-ICPMS. Potential to diagnose Wilson's disease. J Anal At Spectrom 28:98-106
Reynard B, Balter V (2014) Trace elements and their isotopes in bones and teeth: diet, environments, diagenesis, and dating of archeological and paleontological samples. Palaeogeogr Palaeoclimatol Palaeoecol 416:4-16

Reynard L, Pearson J, Henderson G, Hedges R (2013) Calcium isotopes in juvenile milk-consumers. Archaeometry 55(5):946-957

Reynard LM, Henderson GM, Hedges REM (2010) Calcium isotope ratios in animal and human bone. Geochim Cosmochim Acta 74: 3735-3750

Reynard LM, Henderson GM, Hedges REM (2011) Calcium isotopes in archaeological bones and their relationship to dairy consumption. J Archaeol Sci 38:657-664

Richards M, Harvati K, Grimes V, Smith C, Smith T, Hublin J-J, Karkanasc P, Panagopoulou E (2008) Strontium isotope evidence of Neanderthal mobility at the site of Lakonis, Greece using laserablation PIMMS. J Archaeol Sci 35:1251-1256

Richards MP, Fuller BT, Hedges REM (2001) Sulphur isotopic variation in ancient bone collagen from Europe: implications for human palaeodiet, residence mobility, and modern pollutant studies. Earth Planet Sci Lett 191:185-190. doi:10.1016/S0012-821X(01)00427-7

Richards MP, Fuller BT, Sponheimer M, Robinson T, Ayliffe L (2003) Sulphur isotopes in palaeodietary studies: a review and results from a controlled feeding experiment. Int J Osteoarchaeol 13:37-45

Richards MP, Mays S, Fuller BT (2002) Stable carbon and nitrogen isotope values of bone and teeth reflect weaning age at the Medieval Wharram Percy site, Yorkshire, UK. Am J Phys Anthropol 119:205-210

Richter S, Berglund M, Hennessy C (1999) Magnesium isotope ratio measurements by negative thermal ionisation mass spectrometry using molecular fluoride ions. Fresenius J Anal Chem 364:478481. doi:10.1007/s002160051371

Ryan AS, Johanson DC (1989) Anterior dental microwear in Australopithecus afarensis: comparisons with human and nonhuman primates. J Hum Evol 18:235-268

Schauble EA (2004) Applying stable isotope fractionation theory to new systems. Rev Mineral Geochem 55:65-111

Schoeninger MJ, DeNiro MJ (1984) Nitrogen and carbon isotopic composition of bone collagen from marine and terrestrial animals. Geochim Cosmochim Acta 48:625-639

Schoeninger MJ, Moore K (1992) Bone stable isotope studies in archaeology. J World Prehistory 6:247-296

Schoeninger MJ, Hallin K, Reeser H, Valley JW, Fournelle J (2003) Isotopic alteration of mammalian tooth enamel. Int $\mathrm{J}$ Osteoarchaeol 13:11-19. doi:10.1002/oa.653

Sealy J, Armstrong R, Schrire C (1995) Beyond lifetime averages: tracing life histories through isotopic analysis of different calcified tissues from archaeological human skeletons.

Sharp ZD, Atudorei V, Panarello HO, Fernández J, Douthitt C (2003) Hydrogen isotope systematics of hair: archeological and forensic applications. J Archaeol Sci 30:1709-1716

Sime NG, De La Rocha CL, Tipper ET, Tripati A, Galy A, Bickle MJ (2007) Interpreting the Ca isotope record of marine biogenic carbonates. Geochim Cosmochim Acta 71:3979-3989. doi:10.1016/j. gca.2007.06.009

Skulan J, DePaolo DJ (1999) Calcium isotope fractionation between soft and mineralized tissues as a monitor of calcium use in vertebrates. Proc Natl Acad Sci 96:13709-13713

Skulan J, Bullen T, Anbar AD, Puzas JE, Shackelford L, LeBlanc A, Smith SM (2007) Natural calcium isotopic composition of urine as a marker of bone mineral balance. Clin Chem 53:1155-1158. doi:10.1373/clinchem.2006.080143

Skulan J, DePaolo DJ, Owens TL (1997) Biological control of calcium isotopic abundances in the global calcium cycle. Geochim Cosmochim Acta 61:2505-2510. doi:10.1016/S0016-7037(97)00047-1 
Sponheimer M, de Ruiter D, Lee-Thorp J, Späth A (2005) Sr/Ca and early hominin diets revisited: new data from modern and fossil tooth enamel. J Hum Evol 48:147-156

Sponheimer M, Passey BH, De Ruiter DJ, Guatelli-Steinberg D, Cerling T, Lee-Thorp JA (2006) Isotopic evidence for dietary variability in the early hominin Paranthropus robustus. Science 314(5801):980 982

Sponheimer M, Lee-Thorp JA (1999) Isotopic Evidence for the Diet of an Early Hominid, Australopithecus africanus. Science 283 (5400): 368-370

Stenberg A, Andrén H, Malinovsky D, Engström E, Rodushkin I, Baxter DC (2004) Isotopic variations of $\mathrm{Zn}$ in biological materials. Anal Chem 76:3971-3978

Stenberg A, Malinovsky D, Öhlander B, Andrén H, Forsling W, Engström L-M, Wahlin A, Engström E, Rodushkin I, Baxter DC (2005) Measurement of iron and zinc isotopes in human whole blood: preliminary application to the study of HFE genotypes. J Trace Elem Med Biol 19:55-60

Tacail T, Albalat E, Télouk P, Balter V (2014) A simplified protocol for measurement of $\mathrm{Ca}$ isotopes in biological samples. J Anal At Spectrom 29:529-535

Tacail T, Télouk P, Balter V (2016) Precise analysis of calcium stable isotope variations in biological apatites using laser ablation MCICPMS. J Anal At Spectrom 31:152-162

Télouk P, Puisieux A, Fujii T, Balter V, Bondanese VP, Morel A-P, Clapisson G, Lamboux A, Albarede F (2015) Copper isotope effect in serum of cancer patients. A pilot study Metallomics 7:299-308

Touzeau A, Blichert-Toft J, Amiot R, Fourel F, Martineau F, Cockitt J, Hallc K, Flandrois J-P, Lécuyer C (2013) Egyptian mummies record increasing aridity in the Nile valley from 5500 to $1500 \mathrm{yr}$ before present. Earth Planet Sci Lett. doi:10.1016/j.eps1.2013.05.014

Trueman CN, Privat K, Field J (2008) Why do crystallinity values fail to predict the extent of diagenetic alteration of bone mineral? Palaeogeogr Palaeoclimatol Palaeoecol 266:160-167. doi:10.1016/j. palaeo.2008.03.038

Turner BL, Kamenov GD, Kingston JD, Armelagos GJ (2009) Insights into immigration and social class at Machu Picchu, Peru based on oxygen, strontium, and lead isotopic analysis. J Archaeol Sci 36: 317-332

Tütken T, Held P, Herrmann S, Galer S (2015) Combined 888/86Sr and $87 \mathrm{Sr} / 86 \mathrm{Sr}$ in bones and teeth: a toolbox for diet and habitat reconstruction, 25th anniversary of the Goldschmidt conference, Prague, 16th-21st August, Abstract Nr. 2566

Ungar PS, Sponheimer M (2011) The diets of early hominins. Science 334(6053):190-193

von Blanckenburg F, Noordmann J, Guelke-Stelling M (2013) The iron stable isotope fingerprint of the human diet. J Agric Food Chem. doi:10.1021/jf402358n

von Blanckenburg F, Oelze M, Schmid DG, van Zuilen K, Gschwind HP, Slade AJ, Stitah S, Kaufmann D, Piet Swart P (2014) An iron stable isotope comparison between human erythrocytes and plasma. Metallomics 6:2052-2061

von Blanckenburg F, von Wirén N, Guelke M, Weiss DJ, Bullen TD (2009) Fractionation of metal stable isotopes by higher plants. Elements 5:375-380

Van der Merwe NJ, Vogel JC (1978) $813 \mathrm{C}$ content of human collagen as a measure of prehistoric diet in woodland North America. Nature: 815-816

Van Heghe L, Delanghe J, Vlierberghe HV, Vanhaecke F (2013) The relationship between the iron isotopic composition of human whole blood and iron status parameters. Metallomics. doi:10.1039/C3MT00054K
Van Heghe L, Deltombe O, Delanghe J, Depypere H, Vanhaecke F (2014) The influence of menstrual blood loss and age on the isotopic composition of $\mathrm{Cu}, \mathrm{Fe}$ and $\mathrm{Zn}$ in human whole blood. J Anal At Spectrom 29(3):478-482

Van Heghe L, Engström E, Rodushkin I, Cloquet C, Vanhaecke F (2012) Isotopic analysis of the metabolically relevant transition metals $\mathrm{Cu}$, $\mathrm{Fe}$ and $\mathrm{Zn}$ in human blood from vegetarians and omnivores using multi-collector ICP-mass spectrometry. J Anal At Spectrom 27: 1327. doi:10.1039/c2ja30070b

Viers J, Oliva P, Nonell A, Gélabert A, Sonke JE, Freydier R, Gainville R, Dupré B (2007) Evidence of $\mathrm{Zn}$ isotopic fractionation in a soil-plant system of a pristine tropical watershed (Nsimi, Cameroon). Chem Geol 239:124-137

Vogel JC, Van der Merwe NJ (1977) Isotopic evidence for early maize cultivation in New York State. Am Antiq:238-242

Walczyk T (1997) Iron isotope ratio measurements by negative thermal ionisation mass spectrometry using $\mathrm{FeF}$ 4- molecular ions. Int $\mathrm{J}$ Mass Spectrom Ion Process 161:217-227

Walczyk T, von Blanckenburg F (2002) Natural iron isotope variations in human blood. Science 295:2065-2066. doi:10.1126/science.1069389

Walczyk T, von Blanckenburg F (2005) Deciphering the iron isotope message of the human body. Int J Mass Spectrom 242:117-134

Wang Y, Cerling TE (1994) A model of fossil tooth and bone diagenesis: implications for paleodiet reconstruction from stable isotopes. Palaeogeogr Palaeoclimatol Palaeoecol 107:281-289. doi:10.1016 /0031-0182(94)90100-7

Warinner C, Tuross N (2009) Alkaline cooking and stable isotope tissuediet spacing in swine: archaeological implications. J Archaeol Sci 36:1690-1697. doi:10.1016/j.jas.2009.03.034

Weinstein C, Moynier F, Wang K, Paniello R, Foriel J, Catalano J, Pichat S (2011) Isotopic fractionation of $\mathrm{Cu}$ in plants. Chem Geol 286:266-271

Weiss DJ, Mason TFD, Zhao FJ, Kirk GJD, Coles BJ, Horstwood MSA (2005) Isotopic discrimination of zinc in higher plants. New Phytol 165:703-710. doi:10.1111/j.1469-8137.2004.01307.x

Weiss DJ, Rehkdmper M, Schoenberg R, McLaughlin M, Kirby J, Campbell PGC, Arnold T, Chapman J, Peel K, Gioia S (2008) Application of nontraditional stable-isotope systems to the study of sources and fate of metals in the environment. Environ Sci Technol 42:655-664

White CD, Spence MW, Stuart-Williams HLQ, Schwarcz HP (1998) Oxygen isotopes and the identification of geographical origins: the Valley of Oaxaca versus the Valley of Mexico. J Archaeol Sci 25(7): 643-655

Williams JS, White CD, Longstaffe FJ (2005) Trophic level and macronutrient shift effects associated with the weaning process in the Postclassic Maya. Am J Phys Anthropol 128:781-790

Wright C (2014) Calcium isotopes in sheep dental enamel: a new approach to studying weaning and dairying in the archaeological record. DPhil. University of Oxford

Wright LE, Schwarcz HP (1998) Stable carbon and oxygen isotopes in human tooth enamel: identifying breastfeeding and weaning in prehistory. Am J Phys Anthropol 106:1-18

Young ED, Galy A, Nagahara H (2002) Kinetic and equilibrium massdependent isotope fractionation laws in nature and their geochemical and cosmochemical significance. Geochim Cosmochim Acta 66: 1095-1104. doi:10.1016/S0016-7037(01)00832-8

Zazzo A, Monahan FJ, Moloney AP, Green S, Schmidt O (2011) Sulphur isotopes in animal hair track distance to sea. Rapid Commun Mass Spectrom 25(17):2371-2378 